\title{
Adult Polycystic Kidney Disease and CRITICAL IlLNESS INSURANCE
}

\author{
Cristina Gutiérrez* and Angus S. Macdonald ${ }^{\dagger}$
}

\begin{abstract}
Adult polycystic kidney disease (APKD) is a single-gene autosomal dominant genetic disorder leading to end-stage renal disease (ESRD, meaning kidney failure). It is associated with mutations in at least two genes, APKD1 and APKD2, but diagnosis is mostly by ultrasonography. We propose a model for critical illness $(\mathrm{Cl})$ insurance and estimate rates of onset of ESRD from APKD using two studies. Other events leading to claims under $\mathrm{Cl}$ policies are included in the model, which we use to study (a) extra premiums under $\mathrm{Cl}$ policies if the presence of an APKD mutation is known, and (b) the possible costs arising from adverse selection if this information is unavailable to insurers. The extra premiums are typically very high, but because APKD is rare, the possible cost of adverse selection is low. However, APKD is just one of a significant number of single-gene disorders, and this benign conclusion cannot be assumed to apply to all genetic disorders taken together. Moreover, ignoring known genetic risks in underwriting sets a precedent that could have unintended consequences for the underwriting of nongenetic risks of similar magnitude.
\end{abstract}

\section{INTRODUCTION}

\subsection{Adult Polycystic Kidney Disease}

Adult polycystic kidney disease (APKD) is one of the most common single-gene hereditary diseases transmitted in autosomal dominant fashion. Its major feature is progression to end-stage renal disease (ESRD, meaning kidney failure) at relatively young ages. ESRD is not treatable, and death follows rapidly unless renal replacement therapy (RRT, meaning dialysis and/or a kidney transplant) is available.

So far two genes, each causing APKD, have been identified: APKD1 and APKD2. Mutations in APKD1 are more common, accounting for about $85 \%$ of $\mathrm{APKD}$, and are associated with earlier progression to ESRD. It is thought that another gene, APKD3, has yet to be found. The overall frequency of mutations leading to APKD is about 1 per 1,000 (Dalgaard 1957).

\footnotetext{
* Cristina Gutiérrez, Ph.D., is a Professor at Heriot-Watt University, Department of Actuarial Mathematics and Statistics, Endiburgh EH14 4AS, United Kingdom, e-mail: cris@ma.hw.ac.uk.

$\dagger$ Angus S. Macdonald, F.F.A., Ph.D., is a Professor at Heriot-Watt University, Department of Actuarial Mathematics and Statistics, Endiburgh EH14 4AS, United Kingdom, e-mail: A.S.Macdonald@ma. hw.ac.uk.
}

An unusual feature of APKD is that it is detectable by ultrasonography, with high reliability by about age 30. This is an example of genetic information acquired without the direct examination of DNA. In fact, it has proved difficult to develop a reliable DNA-based test for mutations in APKD1 even though it was sequenced in 1995 (see the Appendix), and DNA-based genetic testing is not yet in regular clinical use. In future work we will consider the implications of DNA-based tests for specific mutations, but in this paper we will assume that APKD is detected by ultrasonography.

In the United Kingdom, the Association of British Insurers (A.B.I.) introduced a code of conduct relating to genetic tests and insurance. However, they adopted a narrow definition of "genetic test", based on direct examination of DNA or chromosomes, and for that reason APKD was not included in the list of eight, later seven, single-gene disorders regarded as significant (A.B.I. 1999). Subsequently the Human Genetics Commission has questioned such narrow definitions of genetic information, and it remains to be seen whether or not the insurance treatment of APKD will continue to be distinguished on the basis of the method of detecting it.

In the Appendix, we give a brief account of the 
epidemiology of APKD. The literature is considerable but mostly reports mean or median ages at diagnosis of APKD, at onset of ESRD, and at death. Relatively few studies either give age-related rates of onset of ESRD or allow them to be inferred; we describe two such studies in Section 3 , and these form the basis for this paper.

\subsection{Adult Polycystic Kidney Disease and Critical Illness Insurance}

In the United Kingdom, critical illness (CI) policies cover the event of renal failure. The Association of British Insurers' model definition of renal failure is: "End stage renal failure presenting as chronic irreversible failure of both kidneys to function, as a result of which either regular renal dialysis or renal transplant is initiated" (Dinani et al. 2000, p. 36).

It is simple to formulate (if not to fit) a multiplestate model for pricing and reserving for these policies; we do this in Section 2. In Section 3 we estimate rates of onset of ESRD, from the two studies referred to above.

The model includes CI claims arising from causes other than APKD, and there is no generally agreed model for these in the literature. Macdonald, Waters, and Wekwete (2003a,b) developed a CI model for females; in Section 4 we develop a very similar model and extend it to cover males also.

Life insurance is less straightforward, because survival with ESRD depends entirely on the availability of dialysis and/or kidney transplant. This varies from place to place and from time to time, and there have also been great advances in the effectiveness of both treatments, so it is inappropriate to use past survival rates, perhaps even quite recent survival rates, in future projections.

With the CI insurance model, we consider the costs arising either from using or from not using information about APKD risk in underwriting:

a. In Section 5 we estimate extra premiums appropriate if the presence of an APKD mutation is known

b. In Section 6 we consider the small amount that is known about nondisclosure or adverse selection among persons at risk of $\mathrm{APKD}$, describe a method of modeling adverse selection, and model the potential costs of adverse selection if insurers do not use information about APKD risk, because a moratorium on family histories and/or genetic test results may be in place.

Our conclusions are given in Section 7.

\section{A Mathematical Model of APKD and CRItical Illness InsUrance}

In proposing a model for $A P K D$, we must take account of changes resulting from the availability of effective dialysis. Before, persons might have suffered ESRD leading very quickly to death by uremia (blood poisoning due to the failure of the kidneys to clear toxins), and in these cases the reported endpoint might have been death rather than ESRD. Then a suitable model for CI insurance, which we call Model 1, is shown in Figure 1. Given effective dialysis, however, we assume that those who would have died of uremia will survive ESRD, and therefore for modeling APKD and CI insurance in the future, we propose the model of Figure 2, called Model 2.

Each subgroup of the population will be represented separately by such a model, with different transition intensities. Depending on the purpose, the subgroups may represent APKD genotypes or underwriting classes. The number of genotypes is two because APKD1 and APKD2 are not distinguished, but if underwriting is based on family

\section{Figure 1}

\section{Model 1: Model for APKD in CI Insurance, before Effective Dialysis (Death by Uremia Is an Endpoint)}

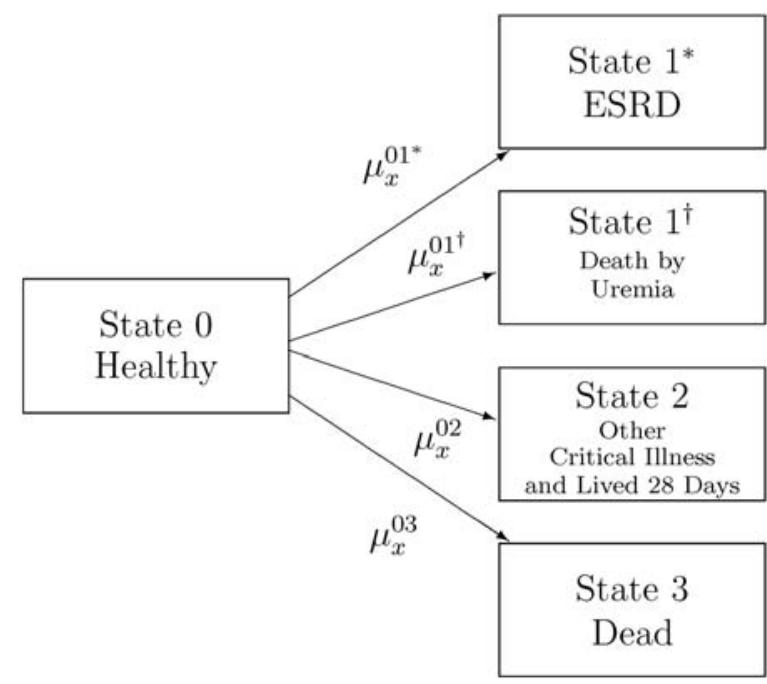


Figure 2

\section{Model 2: Model for APKD in CI Insurance, Given Effective Dialysis (So Those Who Previously Would Have Died of Uremia Survive to Progress to ESRD)}

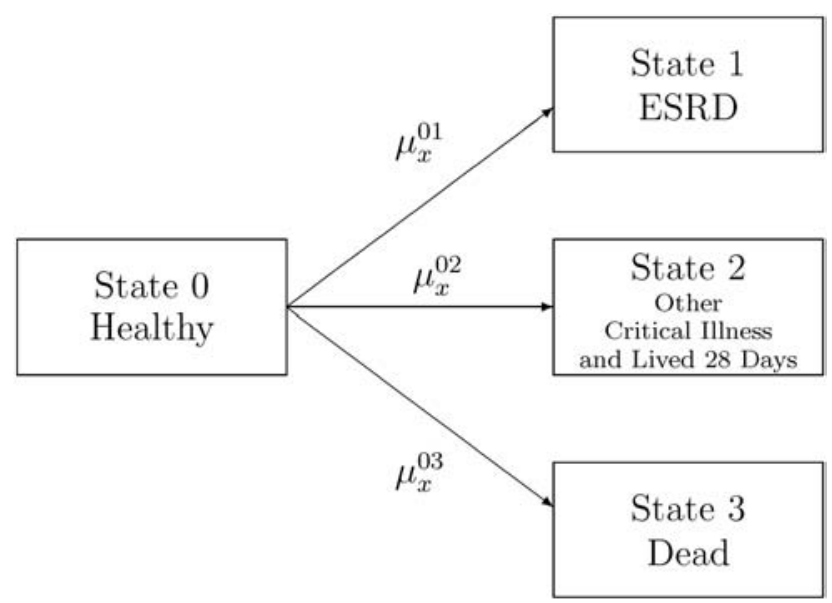

history and not on genotype, there are three relevant subgroups:

a. Persons with no family history, who are not at risk.

b. Persons at risk because of family history, but who do not carry a mutation.

c. Persons at risk because of family history, who do carry a mutation.

To use Model 2, we must estimate the transition intensity $\mu_{x}^{01}$ for each genotype, and the intensities $\mu_{x}^{02}$ and $\mu_{x}^{03}$ for all genotypes. Some of the data are represented by Model 1 ; then we will assume that $\mu_{x}^{01}$ in Model 2 is equal to $\mu_{x}^{01 *}+\mu_{x}^{01 \dagger}$ in Model 1.

We also make the following assumptions, based on Hateboer et al. (1999): age at ESRD does not differ by sex, and there is no parental imprinting, meaning that it is irrelevant whether a mutation is inherited from the mother or from the father.

\section{Estimating of the Rate of Onset of ESRD IN APKD}

\subsection{Age-Dependent Rates of Onset and ESRD}

Rather few studies give age-dependent rates of onset of ESRD, which we need in our work. Two that do will form the basis of our models. Each has strengths and weaknesses.

a. Churchill et al. (1984) studied 140 subjects from 17 kindreds in Canada (100 documented with APKD, 32 predicted, and 8 who died before the study but for whom APKD status was uncertain). They gave a Kaplan-Meier survival curve for the event "first of ESRD or death by uremia" (see Figure 1). Most helpfully (and unusually), they also summarized the underlying data. This study predated the discovery of the APKD1 and APKD2 genes, and their different prognoses, and therefore estimated a rate of onset in respect of both together (as well as APKD3, if it exists).

b. The United States Renal Diseases System (1999) provides incidence counts of ESRD caused by APKD in the U.S. population. These also do not distinguish between APKD1 and APKD2. These can be used with U.S. census data to estimate rates of onset.

See Collett (1994) or Macdonald (1996) for an introduction to Kaplan-Meier estimates of survival functions.

\subsection{Churchill et al. (1984)}

Churchill et al. (1984) gave a Kaplan-Meier estimate of the probability of surviving free of ESRD or death by uremia, but unusually (for medical articles) also reported the numbers of events, censored cases, and persons at risk, allowing the following beta function to be fitted to the intensity $\mu_{x}^{01 *}+\mu_{x}^{01 \dagger}$ in Model 1 by weighted least squares applied to the survival function (attributing the survival probability for each age interval to the end of the interval):

$0.009\left[\frac{\Gamma(13.8)}{\Gamma(10.0) \Gamma(3.8)}\right]\left[\frac{x}{71}\right]^{9.0}\left[1-\frac{x}{71}\right]^{2.8}$,

and we take this to be equal to $\mu_{x}^{01}$ in Model 2. Churchill et al. assumed that all deaths among symptomatic persons were APKD-related and commented that this might have led to understatement of the survival probabilities.

\subsection{The U.S. Renal Diseases System}

The USRDS (1999) provided us with the numbers of cases of ESRD due to APKD in 1994-98 shown in Table 1 (note that there may be 
Table 1

Estimates of Rate of Onset of ESRD Caused by APKD in U.S. Population, 1994-98

\begin{tabular}{|c|c|c|c|c|c|}
\hline $\begin{array}{c}\text { Age } \\
\text { Group }\end{array}$ & $\begin{array}{c}\text { Total } \\
\text { Cases }\end{array}$ & $\begin{array}{c}\text { Person-Years } \\
\text { Exposure } \\
\text { (Population) }\end{array}$ & $\begin{array}{c}\text { Person-Years } \\
\text { Exposure } \\
\text { (Mutation } \\
\text { Carriers) }\end{array}$ & $\begin{array}{c}\text { Rate of } \\
\text { Onset }\end{array}$ & $\begin{array}{c}\text { Standard } \\
\text { Deviation }\end{array}$ \\
\hline $0-19$ & 70 & $380,050,250$ & 380,050 & 0.000184 & 0.000022 \\
$20-44$ & 1,828 & $505,840,000$ & 505,840 & 0.003614 & 0.000085 \\
$45-64$ & 4,850 & $266,122,500$ & 266,122 & 0.018225 & 0.000262 \\
$65-74$ & 1,623 & $93,152,750$ & 93,152 & 0.017423 & 0.000432 \\
$75+$ & 831 & $75,482,250$ & 75,482 & 0.011009 & 0.000382 \\
Total & 9,202 & $1,320,647,750$ & & & \\
\hline
\end{tabular}

underregistration of cases on the system). We estimated person-years exposed to risk based on the total population of the United States for the same years, also shown in Table 1, then estimated the exposure of mutation carriers using the mutation frequency of 1 per 1,000 (Dalgaard 1957). We estimated rates of onset (corresponding to $\mu_{x}^{01}$ in Model 2), assuming these to be constant within each age group, and their standard deviations.

Attributing these rates to the midpoints of the age groups (age 82.5 in the age 75 and over group), we fitted the following beta function by weighted least squares:

$$
0.00653\left[\frac{\Gamma(15.0)}{\Gamma(7.3) \Gamma(7.7)}\right]\left[\frac{x}{129}\right]^{6.3}\left[1-\frac{x}{129}\right]^{6.7}
$$

and the results are shown in Figure 3, compared with the fitted rate of onset based on Churchill et al. (1984).

The corresponding survival curve is shown in

Figure 3

\section{Crude and Graduated Rates of Onset of ESRD (95\% Confidence Intervals)}

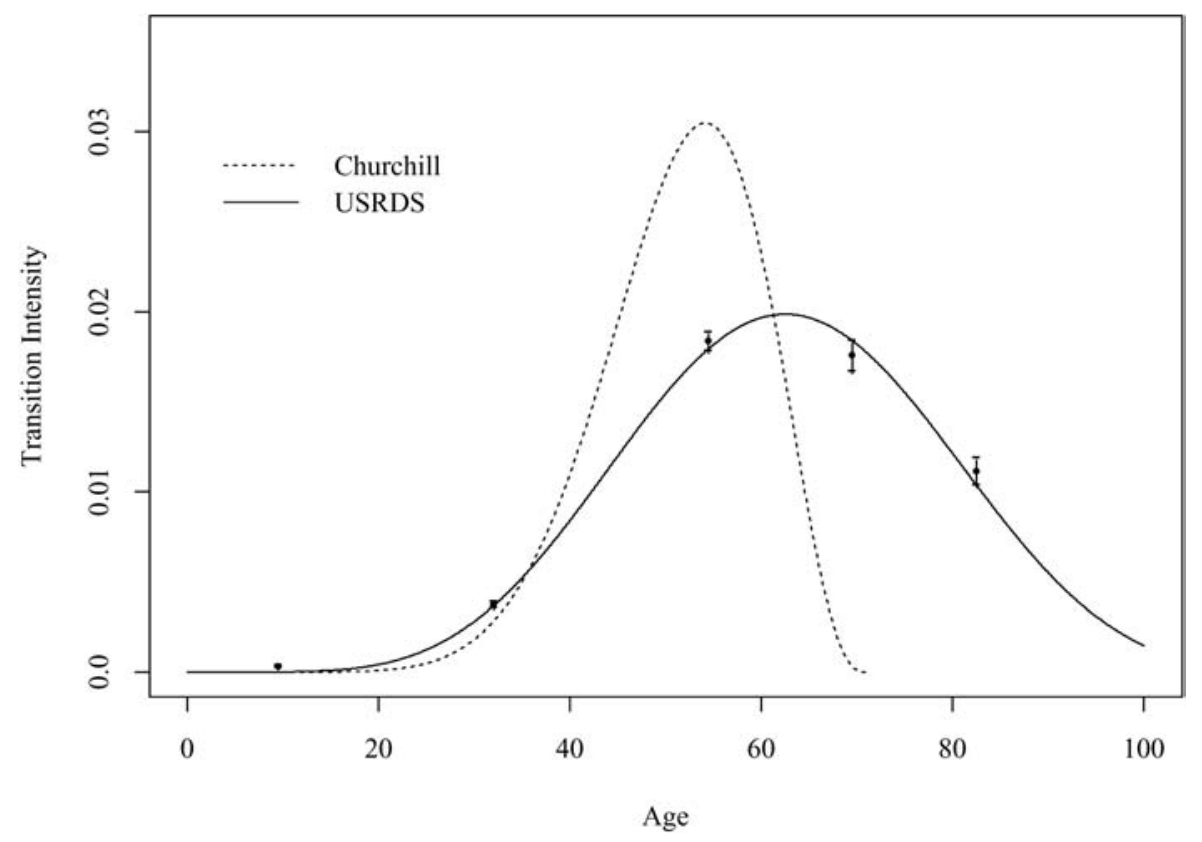

Note: Based on USRDS data, compared with fitted rate of onset based on Churchill et al. (1984) 
Figure 4, compared with that of Section 3.2 and the associated confidence intervals. The two graduated estimates are quite close and seem consistent with Churchill et al.'s (1984) data. In fact, if we adjust the USRDS survival curve to include population mortality as an event of interest instead of a censoring event, it is practically the same as the survival curve fitted to Churchill et al.'s data (not shown). This might be evidence that the treatment of deaths by Churchill et al. (1984) did understate the survival probabilities.

\section{Estimating the Other Intensities IN THe Model}

We estimate $\mu_{x}^{02}$ and $\mu_{x}^{03}$ from a variety of medical and demographical sources. Where these sources cover very low and high ages, we concentrate on ages 20-60 during the fitting process.

For the rate of occurrence of other CI insurance claims, we need rates of onset of cancer, heart attack, stroke, and other minor causes, all adjusted for the condition (usual in CI policies) that the victim must survive for 28 days to claim. We assume all of these to be independent of APKD genotype; this is not completely accurate, but $\mathrm{APKD}$ mutations are sufficiently rare that the effect of ignoring them is negligible. Throughout this section, the nls function in S-PLUS was used for unweighted least squares fitting.

\subsection{Cancer}

We base our calculations on the cancer registrations in 1990-92 (O.N.S. 1999), using midyear population estimates as the exposed to risk. For males, we fitted the functions

$$
\begin{aligned}
\mu_{x}^{02 c}=\exp ( & -11.25+0.105 x) \quad(x<51), \\
\mu_{x}^{02 c}= & \exp (0.2591585-0.01247354 x \\
& +0.0001916916 x^{2}-8.952933 \\
& \left.\times 10^{-7} x^{3}\right) \quad(x \geq 60)
\end{aligned}
$$

with a blending by linear interpolation between ages 51 and 60, and for females

$$
\begin{aligned}
\mu_{x}^{02 c}=\exp (-10.78 & +0.123 x \\
& \left.-0.00033 x^{2}\right) \quad(x<53),
\end{aligned}
$$

Figure 4

\section{Probability of Survival to the First of ESRD or Death by Uremia.}

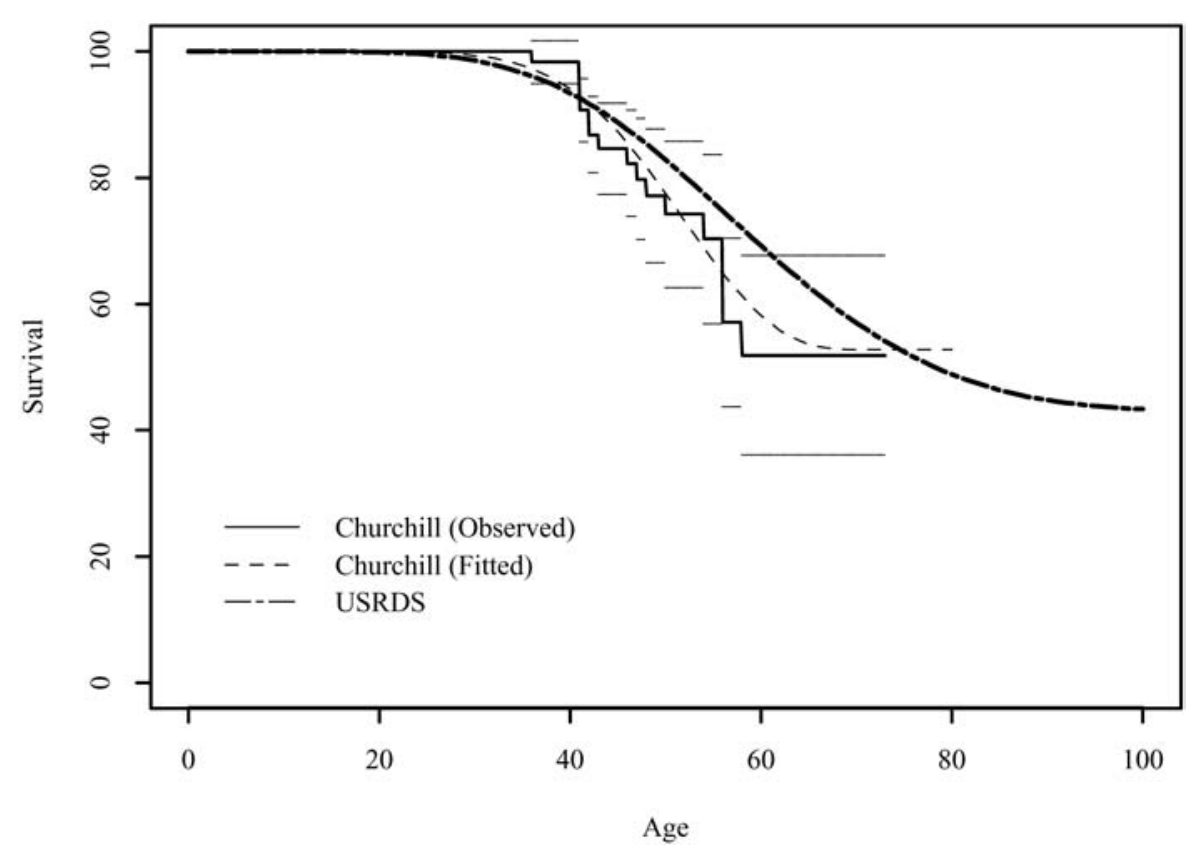

Note: Graduations based on Churchill et al. (1984) and USRDS data, with Churchill et al.'s estimate $(95 \% \mathrm{Cl})$. 
Figure 5

\section{Crude and Graduated Incidence Rates of All Cancers, by Sex}

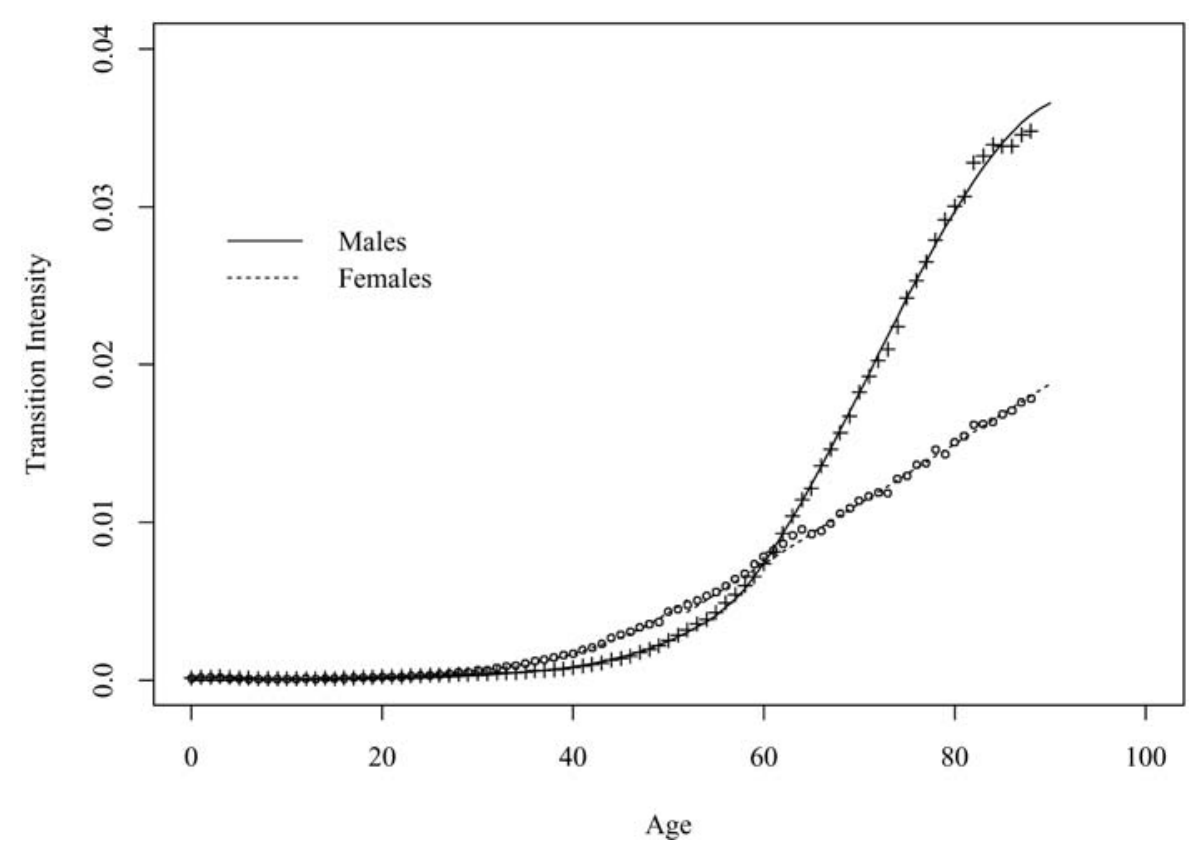

$\mu_{x}^{02 c}=-0.01545632$

$$
+0.0003805097 x \quad(x \geq 53) .
$$

We do not adjust these for surviving 28 days because death within 28 days of cancer diagnosis is uncommon. The results are shown in Figure 5 .

\subsection{Heart Attack}

We used numbers of first-ever cases of heart attacks (ICD 410-414) between September 1991 and August 1992, taken from the Morbidity Statistics from General Practice Survey (McCormick, Fleming, and Charlton 1995). We

could also calculate the exact exposed to risk from this source. The incidence rates are in Table 2. For males we fitted the following functions:

$\mu_{x}^{02 h}=\exp (-13.2238$

$$
+0.152568 x) \quad(x<44)
$$

$$
\begin{aligned}
\mu_{x}^{02 h}=(-0.01245109 & \\
& +0.000315605 x) \quad(x>49)
\end{aligned}
$$

with linear interpolation between ages 44 and 49 . For females we fitted

Table 2

Incidence Rates of First-Ever Heart Attack

\begin{tabular}{|c|c|c|c|c|c|}
\hline Age & Males & Females & Age & Males & Females \\
\hline $0-29$ & 0.00001008 & 0.00001027 & $70-74$ & 0.01060510 & 0.00476737 \\
$30-44$ & 0.00051187 & 0.00011576 & $75-79$ & 0.01195642 & 0.00788896 \\
$45-49$ & 0.00235051 & 0.00046587 & $80-84$ & 0.01749664 & 0.00780025 \\
$50-54$ & 0.00449053 & 0.00101040 & $85-89$ & 0.01015918 & 0.00888135 \\
$55-59$ & 0.00557936 & 0.00215199 & $90-94$ & 0.01470766 & 0.00694985 \\
$60-64$ & 0.00611582 & 0.00278054 & $95-100$ & 0.01828170 & - \\
$65-69$ & 0.00871719 & 0.00415716 & & & \\
\end{tabular}

Source: McCormick, Fleming, and Charlton (1995). 
Figure 6

\section{Crude and Graduated Incidence Rates of All First Heart Attacks, by Sex}

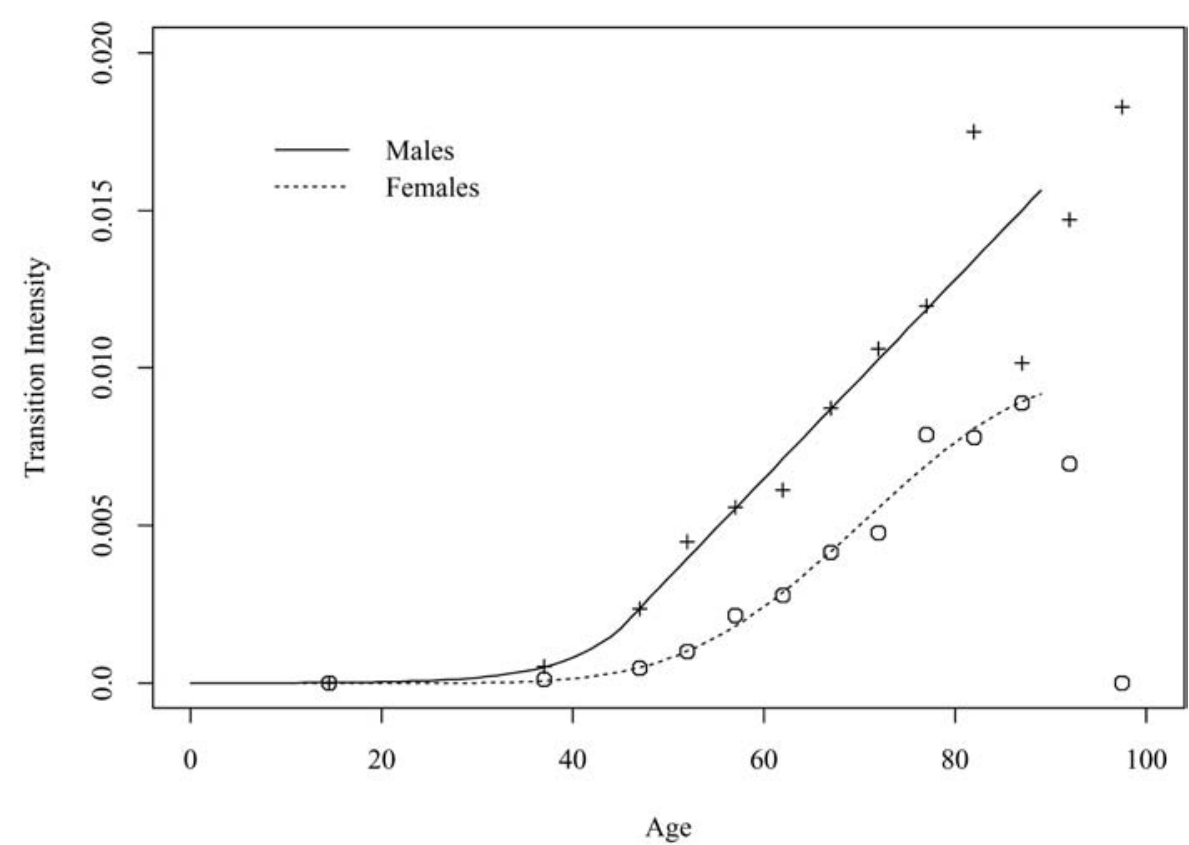

$$
\begin{aligned}
\mu_{x}^{02 h} & =\frac{0.598694}{\Gamma(15.6412)} \\
& \times 0.15317^{15.6412} \exp (-0.15317 x) x^{14.6412}
\end{aligned}
$$

The results are shown in Figure 6.

Let $p_{x}^{h}$ be the 28-day survival probability after the first-ever heart attack. We take 28-day mortality rates following heart attack $\left(q_{x}^{h}=1 \times p_{x}^{h}\right)$ from Dinani et al. (2000). For females $q_{x}^{h}=0.21$ at ages $20-80$. The rates for males are given in Table 3.

\subsection{Stroke}

Stewart et al. (1999) report incidence rates of first-ever stroke, shown in Table 4 . We graduate these using the following functions for males:

$$
\begin{aligned}
\mu_{x}^{02 s}= & \exp (-16.9524+0.294973 x \\
& \left.-0.001904 x^{2}+0.00000159449 x^{3}\right)
\end{aligned}
$$

and for females:

$$
\mu_{x}^{02 s}=\exp (-11.1477+0.081076 x) .
$$

The results are shown in Figure 7.

Again, 28-day survival probabilities $p_{x}^{s}$ are taken from Dinani et al. (2000). For males and females $p_{x}^{s}=(0.9 \times 0.002 x) / 0.9$.

\subsection{Total Rate of Other Critical Illness Claims}

Following Macdonald, Waters, and Wekwete (2003b) and Dinani et al. (2000), we suppose

Table 3

28-Day Mortality Rates $\left(q_{x}^{h}=1-p_{x}^{h}\right)$ for Males Following Heart Attack

\begin{tabular}{|c|c|c|c|c|c|c|c|}
\hline Age & $q_{x}^{h}$ & Age & $q_{x}^{h}$ & Age & $q_{x}^{h}$ & Age & $q_{x}^{h}$ \\
\hline $20-39$ & 0.15 & $47-52$ & 0.18 & $58-59$ & 0.21 & $65-74$ & 0.24 \\
$40-42$ & 0.16 & $53-56$ & 0.19 & $60-61$ & 0.22 & $75-79$ & 0.25 \\
$43-46$ & 0.17 & 57 & 0.20 & $62-64$ & 0.23 & $80+$ & 0.26 \\
\hline
\end{tabular}

Source: Dinani et al. (2000). 
Table 4

Incidence Rates of First-Ever Stroke

\begin{tabular}{|c|c|c|c|c|c|}
\hline Age & Males & Females & Age & Males & Females \\
\hline$<15$ & 0.00002 & 0.00000 & $55-64$ & 0.00308 & 0.00136 \\
$15-24$ & 0.00003 & 0.00005 & $65-74$ & 0.00599 & 0.00445 \\
$25-34$ & 0.00019 & 0.00009 & $75-84$ & 0.00879 & 0.00898 \\
$35-44$ & 0.00032 & 0.00034 & $\geq 85$ & 0.01913 & 0.01887 \\
$45-54$ & 0.00098 & 0.00078 & & & \\
\hline
\end{tabular}

Source: Stewart et al. (1999).

that other minor causes of CI insurance claims amount to $15 \%$ of those arising from cancer, heart attack, and stroke. Therefore,

$\mu_{x}^{02}=1.15\left(\mu_{x}^{02 c}+p_{x}^{h} \times \mu_{x}^{02 h}+p_{x}^{s} \times \mu_{x}^{02 s}\right)$.

The results are shown in Figure 8. The small discontinuity in the incidence rates in respect of females is caused by the introduction of breast cancer screening in the United Kingdom in 1988 (see Macdonald, Waters, and Wekwete 2003a).

Note that we have not attempted to remove cases of APKD from the numbers of kidney failure cases included in the "other minor causes" ad- justment. The double counting is of no importance because all kidney failure cases represent less than $1 \%$ of the total claims in CI.

\subsection{Mortality}

Mortality $\left(\mu_{\mathcal{x}}^{03}\right)$ is based on the English Life Tables No. $15\left(\mu_{x}^{E L T 15}\right)$ with mortality from causes leading to CI claims removed. Following Macdonald, Waters, and Wekwete (2003b), we graduated the ratio $\left(\theta_{x}\right)$ of the number of deaths from such diseases to the total number of deaths in the years 1990-92 (OPCS 1991, 1993a,b; ONS 1999). For males:

Figure 7

Crude and Graduated Incidence Rates of All First Strokes, by Sex

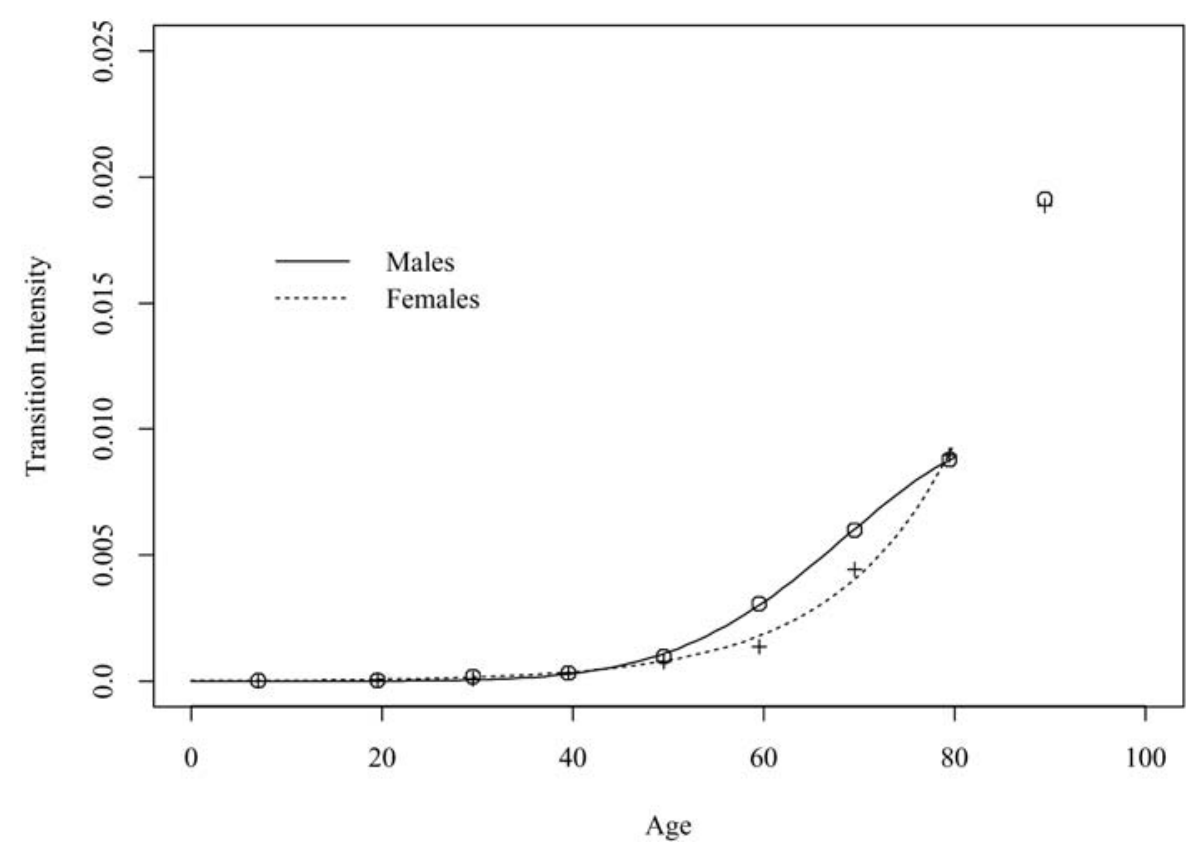


Figure 8

Graduated Incidence Rates of All Critical Illnesses, by Sex

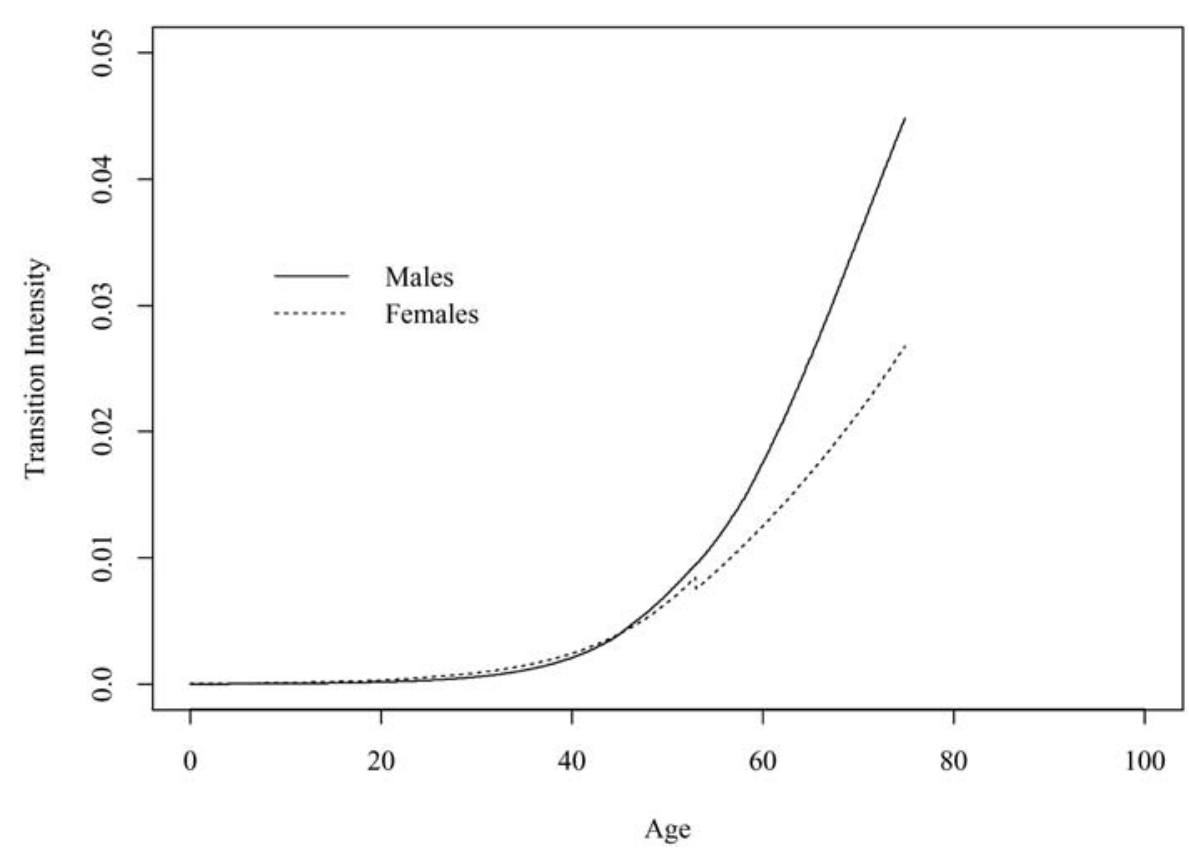

$\theta_{x}=0.0185408+0.0655723 x$

$-0.00667105 x^{2}+0.000223974 x^{3}$

$-0.00000228356 x^{4} \quad(x<30)$,

$\theta_{x}=-0.0280056+0.149759 x-0.00203616 x^{2}$

$$
+0.00000881081 x^{3} \quad(x>44) \text {, }
$$

with a linear blending between ages 30 and 44; for females:

$$
\begin{aligned}
& \theta_{x}=- 0.0261291+0.104641 x \\
&- 0.0118145 x^{2}+0.000467135 x^{3} \\
&- 0.00000579010 x^{4} \quad(x<30), \quad(15) \\
& \theta_{x}=-1.34514+0.0897216 x-0.00119978 x^{2} \\
&+
\end{aligned}
$$

\begin{tabular}{|c|c|c|c|c|c|}
\hline \multirow{3}{*}{$\begin{array}{l}\text { Age at } \\
\text { Entry } \\
\text { (Years) }\end{array}$} & \multirow{3}{*}{$\begin{array}{l}\text { Policy } \\
\text { Term } \\
\text { (Years) }\end{array}$} & \multicolumn{4}{|c|}{ Premium as Percentage of Standard } \\
\hline & & \multicolumn{2}{|c|}{ Churchill et al. Data } & \multicolumn{2}{|c|}{ USRDS Data } \\
\hline & & Males & Females & Males & Females \\
\hline 20 & 10 & $280 \%$ & $205 \%$ & $500 \%$ & $333 \%$ \\
\hline & 20 & 460 & 349 & 532 & 398 \\
\hline & 30 & 489 & 430 & 434 & 377 \\
\hline & 40 & 387 & 389 & 331 & 326 \\
\hline 30 & 10 & 552 & 442 & 554 & 457 \\
\hline & 20 & 537 & 497 & 434 & 403 \\
\hline & 30 & 415 & 435 & 330 & 335 \\
\hline 40 & 10 & 557 & 559 & 389 & 403 \\
\hline & 20 & 421 & 468 & 302 & 332 \\
\hline 50 & 10 & 357 & 422 & 257 & 297 \\
\hline
\end{tabular}

with a linear blending between ages 30 and 35 .

Table 5

\section{Level Net Premium for Level CI Cover for Persons with Known APKD Mutation (Percentage of Premium for Standard Risks)}


Table 6

Main Results from U.S. Surveys

\begin{tabular}{|l|c|c|c|c|}
\hline & \multicolumn{2}{|c|}{ Health Insurance } & \multicolumn{2}{c|}{ Life Insurance } \\
\cline { 2 - 4 } & Fick et al. & Golin et al. & Fick et al. & Golin et al. \\
\hline Response rate & $177 / 344$ & $238 / 354$ & $177 / 344$ & $238 / 354$ \\
Number insured & 150 & 185 & 129 & 174 \\
Cover from own or spouse's employer & $88 \%$ & $84 \%$ & n.a. & $31 \%$ \\
Denied insurance at least once & 28 & 30 & $39 \%$ & 37 \\
Insurer not aware of APKD & 60 & 70 & n.a. & 78 \\
Patient not disclosing APKD diagnosis & 17 & 35 & n.a. & 30 \\
\hline
\end{tabular}

Source: Fick, Johnson, and Gabow (1992) and Golin et al. (1996).

We added back the 28-day mortality following heart attacks and strokes as follows:

$$
\begin{aligned}
\mu_{x}^{03}=\left(1-\theta_{x}\right) \mu_{x}^{E L T 15}+(1- & \left.p_{x}^{h}\right) \mu_{x}^{02 h} \\
& +\left(1-p_{x}^{s}\right) \mu_{x}^{02 s} .
\end{aligned}
$$

\section{Extra Premiums if the APKD Genotype Is Known}

People with APKD cannot obtain life or health insurance once early renal insufficiency is evident. However, applicants with APKD but controlled hypertension and normal renal function might be accepted at a rate of $+200 \%$ to $+300 \%$ for certain life insurance products (Brackenridge and Elder 1998). The rating might be lower for some ages and policy terms if the symptoms tend to be stable.

Using the intensities from Sections 3-4.5, in Model 2 we can calculate level net premiums for a level £1 sum assured under a CI insurance con- tract, for any term and entry age. The expected present values (EPVs) of the benefit, and a level annuity payable continuously while healthy, are found by solving Thiele's equations numerically (we used a fourth-order Runge-Kutta procedure with step size 0.0005 year, and a force of interest of $\delta=0.05$ per annum), and then the insurance premium is found using the usual equivalence principle.

Table 5 shows examples of level net premiums for healthy carriers of an APKD mutation, as a percentage of the level net premiums for noncarriers. Although these are based on population statistics, not insurance statistics, they ought to give a reasonable estimate of the relative extra premiums. All of the premiums are high, bearing in mind that most insurers would decline cases where the premium rating was over $+200 \%$ to $+250 \%$.

The premiums based on Churchill et al. (1984) are higher for all but very young ages and short

Figure 9

Markov Model of Insurance Purchase and CI Insurance Events for Person with Genotype $g_{i}$.

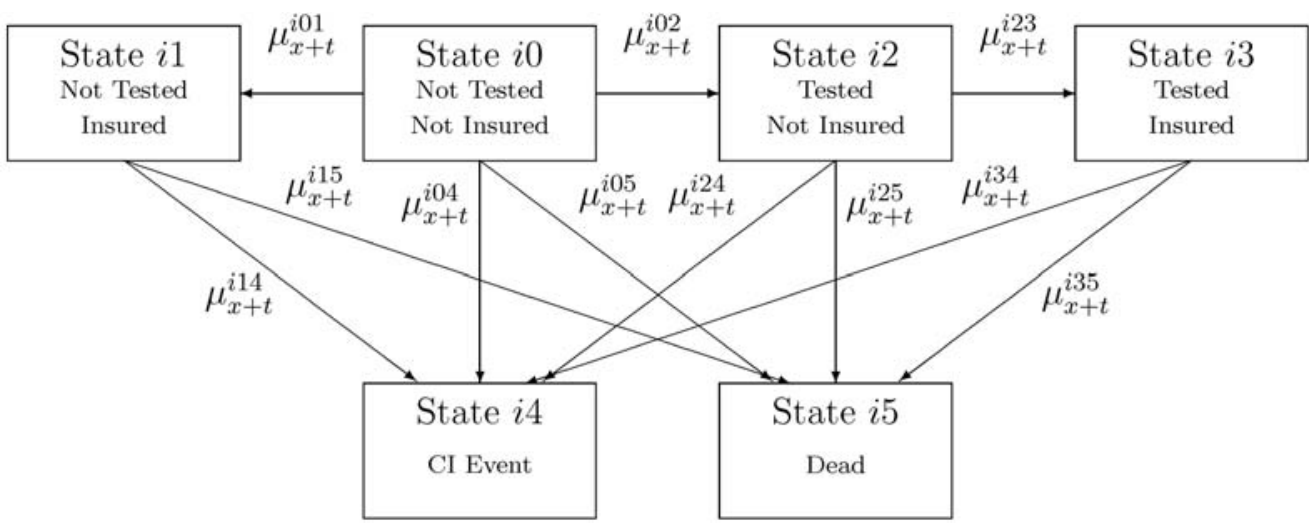


Figure 10

\section{Markov Model Allowing for Family History of APKD}

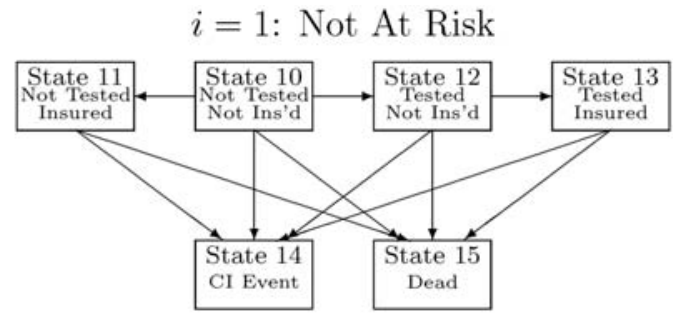

$i=2$ : At Risk, APKD Mutation Absent

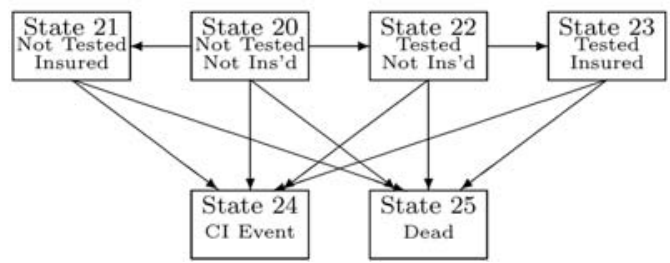

terms. This is perhaps to be expected because of their treatment of deaths (see Section 3.2). The corresponding costs may be regarded as overestimates, or at least as upper limits.

In previous studies of single-gene disorders and insurance (Macdonald and Pritchard 2000, 2001; Macdonald, Waters, and Wekwete, 2003a, b) the penetrance estimates obtained from the epidemiological literature were reduced by up to $75 \%$, to allow for the fact that the studies that had produced them were case-based rather than population-based.

For example, the penetrance of BRCA1 mutations had been estimated by the Breast Cancer Linkage Consortium, an international effort to study families with an extraordinarily high incidence of breast cancer. It was well understood that the penetrance of mutations in the general population, among women not identified because of extreme family histories, would be lower.

The question arises, therefore, whether or not we should make similar adjustments to the penetrance estimates underlying Table 5. We think it unnecessary to do so, because the method of detection and therefore the epidemiology of APKD is different from that of other single-gene disorders:

a. APKD has long been detectable by ultrasonography, so APKD families have been reliably ascertained for a long time. Confirmation of the pres-

\section{$i=3$ : At Risk, APKD Mutation Present}

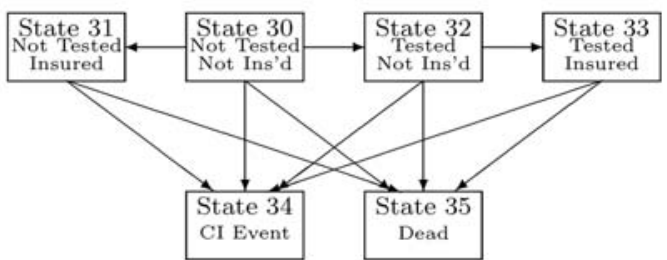

ence, in families, of mutations in some other genes such as BRCA1 has become possible only recently, and in these cases most epidemiology is still based on highly selected families.

b. There is little or no sporadic APKD. When a single gene is but one of many causes of a disorder (breast cancer, for example), complete ascertainment of families with mutations is even more difficult.

\section{Moratoria on the Use of Genetic INFORMATION}

\subsection{Underwriting and Discrimination in the Insurance Market}

Fick, Johnson, and Gabow (1992) and Golin et al. (1996) studied the experience of people with APKD in the U.S. health and life insurance markets. They found evidence of denial of coverage in both markets. In addition the close association of health insurance with employment, and its lack of portability, did limit employment choices. They also found evidence of nondisclosure (see Table 6).

Wertz (personal communication) reports that in the United States APKD is the second most common cause of refusal of life insurance among people at risk. 
Table 7

Possible Underwriting Classes with Three Subpopulations

\begin{tabular}{|c|c|c|c|c|c|c|c|}
\hline \multirow[b]{2}{*}{ No. } & \multirow[b]{2}{*}{$\begin{array}{c}\text { Genetic } \\
\text { Testing } \\
\text { Exists? }\end{array}$} & \multicolumn{3}{|c|}{ Factors Allowed in Underwriting } & \multicolumn{3}{|c|}{ Composition of Underwriting Classes } \\
\hline & & $\begin{array}{l}\text { Family } \\
\text { History }\end{array}$ & $\begin{array}{l}\text { Negative } \\
\text { Test } \\
\text { Results }\end{array}$ & $\begin{array}{c}\text { Positive } \\
\text { Test } \\
\text { Results }\end{array}$ & OR Class & $\begin{array}{l}\text { Rated for Family } \\
\text { History }\end{array}$ & $\begin{array}{c}\text { Rated for } \\
\text { Genetic } \\
\text { Test }\end{array}$ \\
\hline 1 & No & No & n.a. & n.a. & $j=1,2,3$ & & \\
\hline 2 & No & Yes & n.a. & n.a. & $j=1$ & $j=2,3$ & \\
\hline 3 & Yes & No & No & No & $j=1,2,3$ & & \\
\hline 4 & Yes & Yes & No & No & $j=1$ & $j=2,3$ & \\
\hline 5 & Yes & Yes & Yes & No & $j=1$ and & $j=3$ and & \\
\hline & & & & & $j=2(\mathrm{~T})$ & $j=2(U)$ & \\
\hline 6 & Yes & Yes & Yes & Yes & $\begin{aligned} j & =1 \text { and } \\
j & =2(\mathrm{~T})\end{aligned}$ & $\begin{array}{l}j=2(U) \text { and } \\
j=3(U)\end{array}$ & $j=3(\mathrm{~T})$ \\
\hline
\end{tabular}

Notes: $j=1$ not at risk of APKD, $j=2$ at risk of APKD but not mutation carriers, $j=3$ at risk of APKD and mutation carriers. (T) denotes persons who have had a genetic test (including an ultrasound scan), and $(U)$ denotes persons who have not.

\subsection{A Model of Moratoria and Adverse Selection}

We extend Model 2 to allow for having a presymptomatic genetic test, whether DNA-based or by ultrasound, and purchasing CI insurance. Both events are represented by transitions between states in Figure 9.

a. Each of three groups is represented by such a model (Figure 10):

1. Those not at risk because they do not have family history of APKD $(i=1)$

2. Those with a family history of APKD who are not mutation carriers $(i=2)$, and

3 . Those with a family history of APKD who are mutation carriers $(i=3)$.

b. Assuming mutation frequencies of 1 per 1,000 , and dominant inheritance of mutations, the proportions born into each of these groups are $0.998,0.001$, and 0.001 , respectively.

c. A person starts at age $x$ without CI cover and not having had a genetic test.

d. They may buy CI insurance without having a genetic test. The rate at which they do so in the population not at risk will determine the size of the insurance market.

e. People at risk because of family history may take a test that reveals their mutation status (people not at risk will not be tested). They may then buy insurance, and the intensity of this transition may be higher among confirmed mutation carriers. The sums assured purchased by these individuals may also be higher. f. The insurer will group people into underwriting classes according to the information they have, or are allowed to use. Any moratorium on test results or family histories can be represented in this way. Within each underwriting class, the insurer will calculate premiums according to the equivalence principle, assuming that adverse selection is absent. If there is adverse selection, these premiums will be inadequate, and the shortfall will be a measure of the cost of adverse selection.

\subsection{Underwriting Classes}

Macdonald (2003) proposed a model for underwriting and adverse selection related to Mendelian disorders. That study considered a generic, and extreme, model of life insurance in order to estimate upper bounds on the likely costs of adverse selection; here we apply the same method to the real example of APKD and CI insurance.

Table 7 shows which states in the model of Figure 10 are allocated to each of the following underwriting classes, depending on the form of moratorium in force:

a. The Ordinary Rates (OR) class, paying the standard rate of premium

b. Those rated on the basis of a family history of APKD, and

c. Those rated on the basis of a genetic test (of any type) for APKD.

People who are tested with a negative result (no APKD mutation) could be included in the OR 
class, and in practice this is likely to happen. However, when family history is a permissible underwriting factor, as it is at present in the United Kingdom, this is an underwriting decision based on a genetic test result, which strictly speaking may be improper. Therefore we shall consider the possibility that even such advantageous test results are ignored.

\subsection{Methodology}

The methodology was described fully in Macdonald (2003) and will just be summarized here.

a. Starting at age 0 (or any age before APKD first appears) the occupancy probabilities in the model of Figure 10 at all ages up to 60 are found, by solving the Kolmogorov forward equations, starting with the proportions born into each subpopulation (cf. point b in Section 6.2).

b. These occupancy probabilities are used as weights to find the mean intensity from all "healthy" states (all those except the "CI event" and "Dead" states) contained in each underwriting class into the "CI event" state. This mean intensity is the correct currentcost rate of premium in the absence of adverse selection: if it is denoted $\mu_{x+t}^{j}$ at age $x+t$ in the $j$ th underwriting class, then $\mu_{x+t}^{j} d t$ is the expected cost of claims per unit sum assured between ages $x+t$ and $x+$ $t+d t$ in the $j$ th underwriting class, assuming that insurance-buying behavior is uniform within each underwriting class. Therefore, premiums will be payable continuously, at rate $\mu_{x+t}^{j}$ per unit sum assured per annum at age $x+t$ in the $j$ th underwriting class. Using current-cost premiums avoids the problem that level premiums depend on age at entry into an insured state.

c. Assumptions are made about the following intensities (these assumptions do not affect the previous two steps):

1. The rate at which insurance is purchased normally, between ages 20 and 60, defining the size of the insurance market

2. The rate at which insurance is purchased by persons in possession of adverse genetic information (either untested persons in atrisk families or confirmed mutation carri- ers) and the relative amounts of insurance they purchase, and

3. The rate at which genetic testing takes place. d. Using these assumptions and the rates of premiums from point $b$ above, we solve Thiele's equations for the prospective policy values in each state, denoted $V_{x+t}^{j}$ in state $j$ at age $x+t$, backwards from the terminal policy values $V_{60}^{j}=0$ in all states. We use a force of interest of $\delta=0.05$ per annum.

e. This model represents, not a single insurance policy, but an entire market operating between some starting age $x$ and age 60. We calculate the EPV of the losses in this market with and without adverse selection being present; normally the latter should be nil. We also calculate the EPV of all the premiums payable in the market with adverse selection present. Then,

EPV[Loss with adverse selection] -EPV[Loss without adverse selection]

EPV[Premiums with adverse selection]

is the proportion by which all premiums (not only those in the OR class) would have to increase to absorb the cost of the adverse selection.

All the numerical solutions of Kolmogorov's and Thiele's equations were obtained using a RungeKutta algorithm with step size 0.0005 year. These are systems of ordinary differential equations (ODEs) that are soluble by standard numerical methods; see Conte and de Boor (1972) or Press et al. (1982). The Runge-Kutta algorithm is simple, efficient, and easily implemented for any Markov model. We wrote $\mathrm{C}$ programs for this purpose, but modern math packages such as Maple, Mathematica, or Matlab would be quite capable of solving these ODEs.

\subsection{Assumed Intensities}

Here we describe the intensities of insurance purchase and genetic testing. We represent large and small insurance markets by a "normal" rate of purchase of 0.05 and 0.01 per annum, respectively. These rates mean that about $85 \%$ and $30 \%$ of persons, respectively, will buy CI insurance at some time between ages 20 and 60 (ignoring mortality). The former is somewhat larger than the current life insurance market; the latter may be 
Table 8

Percentage Increases in Premium Rates Arising from Severe Adverse Selection

\begin{tabular}{|c|c|c|c|c|c|c|}
\hline \multirow{3}{*}{$\begin{array}{l}\text { Size of } \\
\text { Market }\end{array}$} & \multirow{3}{*}{$\begin{array}{l}\text { Insurance } \\
\text { Purchasing } \\
\text { of At-Risk } \\
\text { Individuals }\end{array}$} & \multirow{3}{*}{$\begin{array}{c}\text { Source of } \\
\text { Data }\end{array}$} & \multicolumn{4}{|c|}{ Moratorium on Using } \\
\hline & & & \multicolumn{2}{|c|}{ All Test Results } & \multicolumn{2}{|c|}{ Adverse Test Results } \\
\hline & & & Females & Males & Females & $\overline{\text { Males }}$ \\
\hline Large & $\begin{array}{l}\text { Normal } \\
\text { Half } \\
\text { Nil } \\
\text { Nil }\end{array}$ & $\begin{array}{l}\text { Churchill et al. } \\
\text { USRDS } \\
\text { Churchill et al. } \\
\text { USRDS } \\
\text { Churchill et al. } \\
\text { USRDS } \\
\text { Churchill et al. } \\
\text { USRDS }\end{array}$ & $\begin{array}{l}0.027 \% \\
0.021 \\
0.052 \\
0.038 \\
0.103 \\
0.073 \\
0.317 \\
0.225\end{array}$ & $\begin{array}{l}0.026 \% \\
0.019 \\
0.049 \\
0.036 \\
0.096 \\
0.068 \\
0.290 \\
0.206\end{array}$ & $\begin{array}{l}0.022 \% \\
0.017 \\
0.040 \\
0.030 \\
0.072 \\
0.051 \\
0.221 \\
0.157\end{array}$ & $\begin{array}{l}0.021 \% \\
0.016 \\
0.038 \\
0.028 \\
0.067 \\
0.048 \\
0.203 \\
0.144\end{array}$ \\
\hline
\end{tabular}

Notes: Moratoria on the use of genetic test results, family history underwriting still allowed. CI market operating between ages 20 and 60 .

comparable with the current CI insurance market (which is growing).

The demand for CI insurance among people at risk, which we might otherwise assume to be increased, might be affected by any extra premium charged in the absence of a moratorium. It is conservative to assume that they then buy less insurance, since the premium charged is adequate; if they were over-insured before a moratorium, the impact of adverse selection would be less. In the large market, we suppose that the rate of insurance purchase of at-risk persons is $100 \%$ of normal, $50 \%$ of normal, or zero. In the small market we assume it is zero.

To represent severe adverse selection, we assume that the rate of insurance purchase of those at risk, and who need not disclose that risk, is 0.25 per annum. This applies both to those with adverse test results and to those in at-risk families, depending on the type of moratorium. There is, therefore, about a $90 \%$ chance that these people will buy insurance within 10 years of discovering their risk status.

We use a constant rate of genetic testing for APKD between ages 20 and 40 equal to 0.035 per annum, and zero at older ages, resulting in about $50 \%$ of people at risk being tested. This is based on

a. The assumption that most presymptomatic testing will take place at relatively young ages, when decisions about reproduction still have to be made,

b. The relatively modest levels of presymptomatic testing that take place in the absence of effective treatments, and

c. The fact that earlier rather than later testing may be more significant for adverse selection.
We find in Section 6.9 that a higher rate of testing has little effect on the results.

\subsection{Different Kinds of Moratoria}

From Macdonald (2001) we expect the effect of a moratorium to depend on whether or not it includes family history. If not, and family history continues to be used in underwriting, the only possible impact on the OR class might be the addition of persons tested and known not to carry a mutation. Assuming them to be otherwise normal, the OR premium rate will be unchanged. If, however, family history may not be used in underwriting, the OR class will be enlarged by the addition of all those at risk of APKD. Even assuming that their insurance-buying behavior is the same as normal, the OR premium rate will rise because they bring higher than average risk. This is not adverse selection; premiums might increase further for that reason too. When we model a moratorium that extends to family history, therefore, we treat these two possible increases in premiums separately.

We consider three possible moratoria:

a. A moratorium on all genetic test results (DNAbased or ultrasound). At the time of writing, use of DNA-based test results would be banned by the moratorium in use in the United Kingdom, but the use of ultrasound tests would be allowed. This seems to be an anomalous position, resulting from the narrow definition of genetic testing adopted by the A.B.I. in 1997.

b. A moratorium on adverse genetic test results only. 
Table 9

\section{Percentage Increases in OR Premium Rates Arising from New Underwriting Classes, and In All Premiums Arising from Severe Adverse Selection, Following a Moratorium on the Use of All Genetic Test Results and Family History}

\begin{tabular}{|c|l|l|l|l|c|}
\hline & & \multicolumn{2}{|c|}{$\begin{array}{c}\text { OR Premium Increases } \\
\text { Arising From New } \\
\text { Underwriting Classes }\end{array}$} & \multicolumn{2}{|c|}{$\begin{array}{c}\text { Premium Increases Arising } \\
\text { From Severe } \\
\text { Adverse Selection }\end{array}$} \\
\cline { 2 - 6 } Size of & Source of & Data & Females & Males & \multicolumn{2}{|c|}{ Females } & Males \\
\hline Large & Churchill et al. & $0.273 \%$ & $0.253 \%$ & $0.126 \%$ & $0.119 \%$ \\
& USRDS & 0.203 & 0.188 & 0.111 & 0.105 \\
& Churchill et al. & 0.266 & 0.240 & 1.001 & 0.920 \\
& USRDS & 0.193 & 0.174 & 0.801 & 0.737 \\
\hline
\end{tabular}

Note: $\mathrm{Cl}$ market operating between ages 20 and 60 .

c. A moratorium on family history and all genetic test results. Some countries, for example, Sweden, have introduced moratoria of this kind.

\subsection{Moratoria on the Use of Genetic Test Results}

Table 8 presents the resulting increases in all premium rates under moratoria on using all, or only adverse, genetic test results. Because some of the increases are very small, and would be $0 \%$ if rounded to the nearer integer, we have shown three decimal places. This is purely in order to display the magnitude of these small increases and is not meant to imply spurious accuracy in respect of any larger figures. The same caveat applies to Tables 9-12. The moratorium has negligible impact in the large market where people at risk tend to buy insurance at normal rates, regardless of extra premiums. Even when these people would not buy insurance at all, except given the opportunity offered by the mora- torium, the impact is very small, less than $1 \%$. In the small market, the premium increases are larger, though still well below 1\%. Bear in mind that this assumes fairly extreme adverse selection, though not any tendency to take out larger than average sums assured.

As expected from Macdonald (2001), adverse selection costs less if only adverse test results are ignored under the moratorium. This is because people who are tested and are not mutation carriers are removed from the underwriting class rated for family history. The latter then contains a higher proportion of mutation carriers, so the premium charged in respect of that class (the mean rate of CI events) is higher.

\subsection{Moratoria on the Use of Genetic Tests and Family History}

Table 9 shows the costs of extending a moratorium to family history, namely, increases in the

Table 10

Percentage Increases in Premium Rates Arising from Severe Adverse Selection

\begin{tabular}{|c|c|c|c|c|c|c|}
\hline \multirow{3}{*}{$\begin{array}{l}\text { Size of } \\
\text { Market }\end{array}$} & \multirow{3}{*}{$\begin{array}{l}\text { Insurance } \\
\text { Purchasing } \\
\text { of At-Risk } \\
\text { Individuals }\end{array}$} & \multirow{3}{*}{$\begin{array}{c}\text { Source of } \\
\text { Data }\end{array}$} & \multicolumn{4}{|c|}{ Moratorium on Using } \\
\hline & & & \multicolumn{2}{|c|}{ All Test Results } & \multicolumn{2}{|c|}{ Adverse Test Results } \\
\hline & & & Females & Males & Females & Males \\
\hline Large & $\begin{array}{l}\text { Normal } \\
\text { Half } \\
\text { Nil } \\
\text { Nil }\end{array}$ & $\begin{array}{l}\text { Churchill et al. } \\
\text { USRDS } \\
\text { Churchill et al. } \\
\text { USRDS } \\
\text { Churchill et al. } \\
\text { USRDS } \\
\text { Churchill et al. } \\
\text { USRDS }\end{array}$ & $\begin{array}{l}0.042 \% \\
0.033 \\
0.080 \\
0.060 \\
0.157 \\
0.113 \\
0.483 \\
0.346\end{array}$ & $\begin{array}{l}0.040 \% \\
0.031 \\
0.076 \\
0.056 \\
0.148 \\
0.106 \\
0.443 \\
0.318\end{array}$ & $\begin{array}{l}0.028 \% \\
0.022 \\
0.047 \\
0.035 \\
0.069 \\
0.051 \\
0.213 \\
0.155\end{array}$ & $\begin{array}{l}0.027 \% \\
0.021 \\
0.044 \\
0.033 \\
0.065 \\
0.047 \\
0.196 \\
0.143\end{array}$ \\
\hline
\end{tabular}

Notes: Moratoria on the use of genetic test results, family history underwriting still allowed. Rate of genetic testing 0.07 per annum between ages 20 and $40 . \mathrm{Cl}$ market operating between ages 20 and 60 . 
Table 11

\section{Percentage Increases in Premium Rates Arising from Severe Adverse Selection Including Higher Sums Assured}

\begin{tabular}{|c|c|c|c|c|c|c|c|}
\hline \multirow{3}{*}{$\begin{array}{l}\text { Size of } \\
\text { Market }\end{array}$} & \multirow{3}{*}{$\begin{array}{l}\text { Insurance } \\
\text { Purchasing } \\
\text { of At-Risk } \\
\text { Individuals }\end{array}$} & \multirow{3}{*}{$\begin{array}{c}\text { Sum } \\
\text { Assured of } \\
\text { Adverse } \\
\text { Selectors } \\
\text { ( } \times \text { Average) }\end{array}$} & \multirow{3}{*}{$\begin{array}{c}\text { Source of } \\
\text { Data }\end{array}$} & \multicolumn{4}{|c|}{ Moratorium on Using } \\
\hline & & & & \multicolumn{2}{|c|}{ All Test Results } & \multicolumn{2}{|c|}{ Adverse Test Results } \\
\hline & & & & Females & Males & Females & Males \\
\hline \multirow{12}{*}{ Large } & \multirow{4}{*}{ Normal } & \multirow[t]{2}{*}{2} & Churchill et al. & $0.054 \%$ & $0.051 \%$ & $0.045 \%$ & $0.042 \%$ \\
\hline & & & USRDS & 0.041 & 0.039 & 0.034 & 0.032 \\
\hline & & \multirow[t]{2}{*}{4} & Churchill et al. & 0.109 & 0.102 & 0.089 & 0.084 \\
\hline & & & USRDS & 0.082 & 0.078 & 0.068 & 0.064 \\
\hline & \multirow[t]{4}{*}{ Half } & \multirow[t]{2}{*}{2} & Churchill et al. & 0.104 & 0.098 & 0.081 & 0.076 \\
\hline & & & USRDS & 0.076 & 0.072 & 0.059 & 0.056 \\
\hline & & \multirow[t]{2}{*}{4} & Churchill et al. & 0.208 & 0.196 & 0.161 & 0.151 \\
\hline & & & USRDS & 0.152 & 0.143 & 0.118 & 0.111 \\
\hline & \multirow[t]{4}{*}{ Nil } & \multirow[t]{2}{*}{2} & Churchill et al. & 0.205 & 0.193 & 0.144 & 0.135 \\
\hline & & & USRDS & 0.146 & 0.137 & 0.102 & 0.096 \\
\hline & & 4 & Churchill et al. & 0.410 & 0.384 & 0.286 & 0.269 \\
\hline & & & USRDS & 0.291 & 0.273 & 0.203 & 0.191 \\
\hline \multirow[t]{4}{*}{ Small } & \multirow[t]{4}{*}{ Nil } & \multirow[t]{2}{*}{2} & Churchill et al. & 0.630 & 0.578 & 0.440 & 0.404 \\
\hline & & & USRDS & 0.448 & 0.411 & 0.313 & 0.287 \\
\hline & & \multirow[t]{2}{*}{4} & Churchill et al. & 1.251 & 1.148 & 0.872 & 0.800 \\
\hline & & & USRDS & 0.889 & 0.816 & 0.621 & 0.570 \\
\hline
\end{tabular}

Notes: Moratoria on the use of genetic test results, family history underwriting still allowed. Adverse selectors take out two or four times the average sum assured. $\mathrm{Cl}$ market operating between ages 20 and 60 .

OR premium rates assuming those previously charged higher premiums become "normal" insurance purchasers, and additional increases in all premiums caused by severe adverse selection (rate of insurance purchase 0.25 per annum).

The premium increases, although still very small in absolute terms, are much higher than those for the moratoria on the use of genetic test results alone. The cost of extending the OR class, with no adverse selection, is about the same for both the large and the small market. In the large market, the effect of adverse selection is less, while in the small market it is much greater. The balance between these two costs depends on the mutation frequencies as well as penetrance. The results for males and females are broadly the same.

\subsection{Sensitivity Analysis}

In this section we present a sensitivity analysis in respect of some of the key assumptions we used in our model, namely, the rate of genetic testing, and the sums assured purchased by "adverse selectors."

We do not show the results of assuming a less severe level of adverse selection, which we would normally regard as necessary, because the costs already shown are so small that it would be of little interest. We just note that our severe assumed level of adverse selection might not consider the real financial circumstances of people at risk; even when they know their risk, their appetite for insurance may be limited by other demands on their incomes. We found that a more modest level of adverse selection (insurance purchased at twice the normal rate) will have a negligible impact in costs of premium under any of the moratoria.

We double the rate of genetic testing to 0.07 per annum, between ages 20 and 40, assuming that medical advances encourage the early diagnosis and treatment of APKD among people at risk. This rate implies that about $75 \%$ of the people at risk will have a genetic test. We do not assume that the medical advances that lead to this increased level of testing reduce the claims experience of CI insurance, which is a conservative position. Table 10 (compare with Table 8) shows increases in premium rates under moratoria on the use of genetic test results, family history still being useable. Costs increase moderately under the moratorium on the use of all genetic test results, especially in the small market, as we expected. Under a mor- 
Table 12

\section{Percentage Increases in All Premiums Arising From Severe Adverse Selection, Following a Moratorium on The Use of All Genetic Test Results and Family History}

\begin{tabular}{|c|c|c|c|c|c|}
\hline \multirow{3}{*}{$\begin{array}{l}\text { Size of } \\
\text { Market }\end{array}$} & \multirow{3}{*}{$\begin{array}{c}\text { Source of } \\
\text { Data }\end{array}$} & \multicolumn{4}{|c|}{ Sums Assured of Adverse Selectors } \\
\hline & & \multicolumn{2}{|c|}{$2 \times$ Average } & \multicolumn{2}{|c|}{$4 \times$ Average } \\
\hline & & Females & $\overline{\text { Males }}$ & Females & Males \\
\hline $\begin{array}{l}\text { Large } \\
\text { Small }\end{array}$ & $\begin{array}{l}\text { Churchill et al. } \\
\text { USRDS } \\
\text { Churchill et al. } \\
\text { USRDS }\end{array}$ & $\begin{array}{l}0.252 \% \\
0.439 \\
1.995 \\
1.804\end{array}$ & $\begin{array}{l}0.238 \% \\
0.414 \\
1.835 \\
1.660\end{array}$ & $\begin{array}{l}0.503 \% \\
1.093 \\
3.963 \\
3.788\end{array}$ & $\begin{array}{l}0.474 \% \\
1.160 \\
3.648 \\
3.488\end{array}$ \\
\hline
\end{tabular}

Notes: Adverse selectors take out two or four times the average sum assured. $\mathrm{Cl}$ market operating between ages 20 and 60 .

atorium on the use only of adverse genetic test results, the cost are practically the same, because of the more homogeneous underwriting groups. Clearly, even very high levels of genetic testing will not alter any conclusions.

As mentioned in Macdonald (2001) and confirmed by numerical results not shown here, the rate of testing will make no difference under a moratorium extended to family history, because we have assumed that knowledge of familial risk alone may lead to the same levels of insurance purchase as an adverse test result might. Then the outcomes in Table 9 are unchanged.

Macdonald (1999) reported that above-average sums assured taken out by adverse selectors contribute significantly to the cost of adverse selection. Tables 11 and 12 show these costs assuming adverse selectors buy two or four times the average sum assured; Table 11 shows the effect if moratoria cover only genetic test results, while Table 12 shows the effect of a moratorium extending to family history. In the latter case, the premium increases caused by the expanded OR underwriting class are the same as in Table 9, only the costs of adverse selection are different. The increases are almost proportional to the excess sum assured. Now the market size begins to be very important; premium increases of up to $5 \%$ are found in the small market. However, this assumes very severe adverse selection, and the extent to which this might actually occur is debateable.

Finally, note that our costs of adverse selection depend on the assumed mutation frequency of about 1 per 1,000 in the population (though the illustrations in Table 5 do not). With such a small frequency, changes in costs are practically pro- portionate to any change in the frequency, so we omit any figures.

\subsection{Comparison of Data Sources}

In all cases, the costs of adverse selection were slightly lower if the rates of onset of ESRD were based on the USRDS (1999). However, the differences were small and do not materially affect any conclusions. Given the small amount of data available from Churchill et al. (1984), their treatment of deaths, and the use of an assumed mutation frequency in obtaining rates of onset from the USRDS data, the agreement is in fact quite good.

\section{Conclusions}

We developed a multiple-state model of APKD and other causes of claim under a CI insurance policy. The transition intensities of onset of ESRD were based on two sources; Churchill et al. (1984) and the USRDS (1999). We did not, in this study, consider separately the APKD1 and APKD2 genes. Our conclusions were as follows:

a. If someone is known to be an APKD mutation carrier, the extra CI insurance premium that might be charged (Table 5) would not be less than about $+150 \%$ and would usually exceed the acceptable maximum of about $+200 \%-250 \%$ typical in current underwriting. It varies greatly by entry age and policy term.

b. The cost of adverse selection, in terms of uniform premium increases, depends stronǵly on market size and any tendency to take out very high sums assured. If a moratorium covers genetic test results but not family history, the costs of even very severe adverse selection are 
extremely small, less than $1 \%$ of total premiums.

c. Extending a moratorium to family history could result in small premium increases (less than $0.5 \%)$ even if no adverse selection took place, just by admitting people at risk of APKD to the ordinary rates class. Adverse selection above and beyond that could, at worst, lead to premium increases of the order of $1 \%$ in a large market and 5\% in a small market. Above average sums assured is the most significant contributor to these costs. We note the limit of $£ 300,000$ for CI insurance in the recently introduced moratorium in the United Kingdom, above which genetic test results might be used if approved by GAIC.

d. Even disregarding the latter premium increases as being based on adverse selection more severe than would be likely in practice, the small increases that remain are not necessarily negligible, because they relate to just one of several single-gene disorders.

Macdonald (1997, 1999, 2003) obtained rather imprecise bounds on the costs of adverse selection arising from moratoria on genetic information, based on generic models of genetic disorders. While that is useful for certain purposes, it is desirable in pursuing an evidence-based approach to policy in this area to have a clearer idea of the consequences of various options, based on knowledge of specific genes and their epidemiology.

This paper is a small step in a program with that aim. It shows only a small part of the whole picture and in our view does not by itself show that any moratorium would be harmless to the broader interests of the insurance industry and its various stakeholders. APKD, with a population frequency of about 1 per 1,000 , accounts for perhaps $10 \%$ or more of single-gene disorders that might affect CI insurance. Some, like Huntington's disease, are rarer but have equally early onset, while others, like hereditary nonpolyposis colorectal cancer, may be more common (Pasternak 1999) but have outcomes that may soon be improved by genetic screening and early intervention.

A further difficulty with neurological genetic disorders is that a CI claim might not be made at onset but at some later stage of the disorder. It is therefore difficult to extrapolate from APKD to other genetic disorders.

In particular, the small (in absolute terms) costs of adverse selection that we have found should not lead automatically to the conclusion that APKD, on its own, is easily ignorable in insurance underwriting. That would set a precedent, the consequences of which are hard to foresee. To the extent that genetic information is regarded as special, the precedent might be confined to that area, but to the extent that genetic information might come to be seen as just another risk factor, any small group presenting higher risks might be able to press a case, and then we may ask why the number of people affected plays any part in defining their rights.

In future work we will extend these results to life insurance and examine separately insurance implications of mutations in the two genes known to cause APKD, APKD1, and APKD2, which lead to very different prognoses.

\section{ACKNOWLedGments}

This work was carried out at the Geneties and Insurance Research Centre at Heriot-Watt University. We would like to thank the sponsors for funding, and members of the Steering Committee for helpful comments at various stages. We would like to thank the U.S. Renal Diseases System for providing data.

\section{Appendix}

\section{Adult Polycystic Kidney Disease}

\section{A1 General Features}

APKD is a degenerative disorder characterized by the growth of numerous cysts in both kidneys, which lead to the onset of symptoms and eventually to ESRD. APKD is one of the leading causes of ESRD and the need for RRT. It shows strongly Mendelian autosomal dominant inheritance, suggesting that one or more individual genes, acting singly, are its cause, a hypothesis now confirmed by discovery of at least two such genes. Mutations causing APKD have a population frequency of about 1 per 1,000 (Dalgaard 1957). We may distinguish several stages; unfortunately different 
Table 13

\section{Studies of Age at Onset or Diagnosis}

\begin{tabular}{|c|c|c|c|c|}
\hline Reference & Subgroup & $\begin{array}{l}\text { Number } \\
\text { in Study }\end{array}$ & $\begin{array}{c}\text { Mean } \pm \text { SE } \\
\text { or } \\
\text { (Median) } \\
\text { Age }\end{array}$ & Range \\
\hline $\begin{array}{l}\text { Bogdanova et al. (1995) } \\
\text { Braasch and Schacht (1933) } \\
\text { Dalgaard (1957) } \\
\text { De Bono and Evans (1977) } \\
\text { Gonzalo et al. (1990) } \\
\text { Hadimeri et al. (1997) } \\
\text { Hateboer et al. (1999) } \\
\text { Papadopoulou et al. (1999) } \\
\text { Ravine et al. (1992) } \\
\text { Torra et al. (1996) } \\
\text { Wright et al. (1993) }\end{array}$ & $\begin{array}{l}\text { Linked to APKD1/2 } \\
\text { Not linked } \\
\text { All } \\
\text { All } \\
\text { Accidental discovery } \\
\text { Uremic symptoms } \\
\text { Loin pain/urinary infection } \\
\text { Hematuria } \\
\text { Abdominal mass } \\
\text { Dyspepsia } \\
\text { Subarachnoid hematuria } \\
\text { All } \\
\text { Asymptomatic } \\
\text { Normal renal function } \\
\text { Chronic renal failure } \\
\text { All } \\
\text { APKD1 } \\
\text { APKD2 } \\
\text { All } \\
\text { APKD1 } \\
\text { APKD2 } \\
\text { APKD1 } \\
\text { APKD2 } \\
\text { APKD1 } \\
\text { APKD2 }\end{array}$ & $\begin{array}{r}21 \\
14 \\
193 \\
313 \\
10 \\
9 \\
26 \\
15 \\
15 \\
1 \\
2 \\
107 \\
9 \\
30 \\
68 \\
114 \\
223 \\
204 \\
85 \\
197 \\
39 \\
146 \\
20 \\
49 \\
17\end{array}$ & $\begin{array}{c}45.4 \pm 13.2 \\
47.9 \pm 15 \\
38.8 \\
40.7 \\
30.6 \\
47.5 \\
35.1 \\
36.8 \\
43 \\
41 \\
35 \\
45.9 \pm 14 \\
27.0 \pm 5 \\
40.5 \pm 13 \\
50.8 \pm 12 \\
37.0 \pm 11 \\
(42) \\
(56) \\
26 \pm 12 \\
(44.8) \\
(69.1) \\
27.4 \pm 13.4 \\
41.4 \pm 16.9 \\
25 \pm 13 \\
37 \pm 11\end{array}$ & $\begin{array}{r}18-83 \\
22-36 \\
18-75 \\
18-83 \\
38.6-45.4 \\
52.1-59.9\end{array}$ \\
\hline
\end{tabular}

authors use the word "penetrance" to describe the age-dependent probabilities of reaching one or other of these stages, so it is necessary to be careful with definitions:

a. A period before eysts have developed to a level detectable by ultrasound.

b. A period during which clinical symptoms are absent but cysts are detectable. The cysts can be reliably detected by ultrasonography long before onset of symptoms occurs. Ultrasonography can detect APKD with $100 \%$ sensitivity in individuals at risk older than 30 years (Nicolau et al. 1999) and may therefore be called a genetic test in a broad sense. However, ultrasonography falls outside a narrow definition of "genetic test," based on direct examination of DNA or chromosomes, and for that reason APKD was not covered by the code of conduct introduced in 1997 by the Association of British Insurers (A.B.I. 1999). Dobin et al. (1993) estimated the penetrance to the development of detectable cysts to be over $70 \%$ by age 30 , over $95 \%$ by age 50 , and $99 \%$ by age 55 .

c. The development of symptoms (commonly urinary tract infection, haematuria, hypertension, loin pain, and gastrointestinal complications). Most sufferers develop symptoms in their third or fourth decade of life.

d. Progression to ESRD. Some authors report that the probability of being alive and not having ESRD is $75-80 \%$ by age $50,50-55 \%$ by age 60 , and $25-50 \%$ by age 70 (Brendan and Parfrey 1991; Churchill et al. 1984; Parfrey et al. 1990). Torra et al. (1995) reported that the progression to ESRD of APKD varies widely among different families but is rather homogeneous within families.

Other extrarenal manifestations associated with APKD include cysts in the liver (most common), pancreas, lungs, spleen, ovaries, testes, epididymis, thyroid, uterus, broad ligament, and bladder. Patients with APKD have an increased risk of intracranial aneurysm or subarachnoid haemorrhages (Watson and Torres 1996).

The prevalence of ESRD due to APKD is lower than the frequency of mutations, approximately 1 in 2,500 among populations of European origin, which is around $6-9 \%$ of all cases of ESRD in Europe (Bear 1995). 
Table 14

Studies of Age at ESRD

\begin{tabular}{|c|c|c|c|c|}
\hline Reference & Subgroup & $\begin{array}{l}\text { Number } \\
\text { in Study }\end{array}$ & $\begin{array}{l}\text { Mean } \pm \text { SE or } \\
\text { (Median) Age } \\
\text { at ESRD }\end{array}$ & Range \\
\hline Bogdanova et al. (1995) & $\begin{array}{l}\text { Linked to APKD1/2 } \\
\text { Not linked }\end{array}$ & $\begin{array}{r}18 \\
6\end{array}$ & $\begin{array}{l}50.9 \pm 11.5 \\
52.0+14.1\end{array}$ & \\
\hline Demetriou et al. (2000) & APKD2 & 11 & 66.3 & $69-74$ \\
\hline Franz and Reubi (1983) & All & 17 & $47.8 \pm 10.3$ & $27-68$ \\
\hline \multirow{9}{*}{$\begin{array}{l}\text { Geberth et al. (1995a) } \\
\text { (Study of parents and } \\
\text { children) }\end{array}$} & All & 74 pairs & $(53.7)$ & $30-72$ \\
\hline & Fathers & 40 & $(51.8)$ & $32-68$ \\
\hline & Sons (APKD from father) & 29 & $(51.7)$ & $44-64$ \\
\hline & Daughters (APKD from father) & 11 & $(51)$ & $30-68$ \\
\hline & Mothers & 34 & $(56.4)$ & $45-66$ \\
\hline & Sons (APKD from mother) & 16 & $(55)$ & $30-68$ \\
\hline & Daughters (APKD from mother) & 18 & $(57.2)$ & $34-72$ \\
\hline & $1950-74$ & 74 & $(58)$ & $47-65$ \\
\hline & $1975-85$ & 59 & (59) & $53-71$ \\
\hline \multirow[t]{2}{*}{ Geberth et al. (1995b) } & Propositi & 57 & $50.76 \pm 9.15$ & \\
\hline & Censored & 94 & $50.21 \pm 9.13$ & \\
\hline \multirow[t]{6}{*}{$(\mathrm{NP}=$ nonaffected parent $)$} & NP hypertensive & 23 & $(49)$ & $26-64$ \\
\hline & To Son & 11 & $(46.4)$ & $30-57$ \\
\hline & To Daughter & 12 & $(48)$ & $26-64$ \\
\hline & NP normotensive & 34 & (54) & $28-82$ \\
\hline & To Son & 16 & $(49.6)$ & $28-63$ \\
\hline & To Daughter & 18 & $(56.6)$ & $43-82$ \\
\hline Gonzalo et al. (1990) & All & 40 & $52.7 \pm 9.9$ & $26-75$ \\
\hline Gonzalo et al. (1996) & All & 45 & 50 & $26-78$ \\
\hline \multirow[t]{2}{*}{ Gretz et al. (1989) } & Males & 73 & $(52.5)$ & $33-70.3$ \\
\hline & Females & 85 & $(58)$ & $27.1-78.9$ \\
\hline Hadimeri et al. (1997) & All & 114 & $51 \pm 8$ & \\
\hline \multirow[t]{4}{*}{ Hateboer et al. (1999) } & APKD1 & 110 & $(54.3)$ & $52.7-55.9$ \\
\hline & APKD2 & 40 & $(74)$ & $67.2-80.8$ \\
\hline & Females & & (71) & $67.2-74.8$ \\
\hline & Males & & $(67.3)$ & 64.9-69.7 \\
\hline \multirow[t]{4}{*}{ Johnson and Gabow (1997) } & Diagnosis $<$ age 30 & 428 & (49) & \\
\hline & Diagnosis $>$ age 30 & 386 & (59) & \\
\hline & APKD1 & 287 & (53) & \\
\hline & APKD2 & 34 & $(68)$ & \\
\hline \multirow[t]{3}{*}{ Parfrey et al. (1990) } & All & 152 & $59.3 \pm 1.8$ & \\
\hline & APKD1 & 134 & $56.7 \pm 1.9$ & \\
\hline & Non-APKD1 & 18 & $69.4 \pm 1.7$ & \\
\hline \multirow[t]{2}{*}{ Ravine et al. (1992) } & APKD1 & 197 & (56) & $0.3-71$ \\
\hline & Non-APKD1 & 39 & (71.5) & $42-80$ \\
\hline \multirow{2}{*}{ Torra et al. (1996) } & APKD1 & 38 & $53.4 \pm 0.97(52)$ & \\
\hline & APKD2 & 4 & $72.7 \pm 2.60(71)$ & \\
\hline
\end{tabular}

\section{A2 Genetics of Adult Polycystic Kidney Disease}

Mutations at at least two and possibly three genetic loci are responsible for APKD.

a. The APKD1 gene was located on chromosome 16 in many studies in the late 1980s and early 1990 s, finally being sequenced in 1995 (International Polycystic Kidney Disease Consortium 1995). Mutations in APKD1 are responsible for around $84-95 \%$ of all cases (Kimberling et al. 1990; Hateboer et al. 1999); Bogdanova et al. (1995), Johnson and Gabow (1997), Parfrey et al. (1990), Ravine et al. (1992), Torra et al. (1996), and Wright et al.
(1993) give evidence that APKD1 mutations are associated with the most severe form of the disease.

b. The APKD2 gene, on chromosome 4, was likewise gradually hunted down and was sequenced in 1996 (Mochizuki et al. 1996; Schneider et al. 1996). It is responsible for almost all the remaining cases and is associated with a milder form of the disease.

c. Some authors provide evidence of a third locus (Ariza et al. 1997; de Almeida et al. 1999), but this potential APKD3 gene remains to be found.

APKD1 and APKD2 phenotypes have autosomal dominant inheritance. 
Following the discovery of APKD1 and APKD2, it might be expected that DNA-based genetic tests would quickly enter clinical practice, at least for diagnosis and counseling. However, the APKD1 gene shows that finding the gene responsible for a disease need not lead straight to a reliable DNAbased test for mutations in that gene. Large portions of the APKD1 gene are homologous to (that is, have the same sequence of bases as) other parts of chromosome 16. Many of the techniques used to analyze DNA had difficulty in distinguishing between homologous regions of DNA, and in the first few years after the discovery of APKD1, most known mutations were found in a small part of the gene that is not repeated elsewhere. Only recently has it been possible to screen the whole gene for mutations (Thomas et al. 1999; Rossetti et al. 2001).

The precise mechanism of APKD is still not known, but the fact that not all kidney cells develop cysts suggests that APKD may be recessive at the cellular level, and individual cells need the functioning copy of the gene to be knocked out by a "second hit" for a cyst to develop. There is some evidence that the gene products may interact as part of a larger complex. Koptides et al. (2000) reported a case of APKD in which the cysts had a germline (inherited) mutation in APKD1 and a somatic mutation (arising after birth) in APKD2.

\section{A3 Prognosis}

Tables 13 and 14 summarize studies of age at diagnosis and at onset of ESRD of APKD patients.

Gabow et al. (1992) reported several factors associated with worse mean renal function at a given age, namely, an APKD1 mutation, younger age at diagnosis, male gender, hypertension, increased left ventricular mass, hepatic cysts in women, three or more pregnancies, gross hematuria, urinary tract infections in men, and renal size expressed as renal volume. Gender of affected parent, mitral valve prolapse, intracranial aneurysms, any pregnancy, hepatic cysts in men, and urinary tract infections in women did not show such association.

The improvement of ultrasound techniques allows earlier identification of asymptomatic individuals, who can then start a program to control their blood pressure. For example, Dobin et al. (1993) reported that age at detection was nor- mally distributed with mean 20 years and standard deviation 15.94 years, lower than in previous studies (Dalgaard 1957; Bear et al. 1984). The age of full clinical penetrance in Dobin et al. (1993) is 58, almost the same as in Dalgaard (1957).

\section{References}

Ariza, M., V. Alvarez, R. Marin, S. Aguado, C. Lopez-Larrea, J. Alvarez, and M. Menendez. 1997. "A Family with a Milder Form of Adult Dominant Polycystic Kidney Disease not Linked to the PKD1 (16p) or PKD2 (4q) Genes," Journal of Medical Genetics 34(7): 587-89.

Association of British Insurers (A.B.I.), 1999. Genetic Testing: ABI Code of Practice, revised August 1999. London: A. B. I.

BeAR, J. 1995. "ADPKD: Practical Implications of Population Genetics," Contributions to Nephrology 115: 20-27.

Bear, J., P. Mcmanamon, J. Morgan, R. Payne, H. Lewis, M. Gault, and D. Churchill. 1984. "Age at Clinical Onset and at Ultrasonographic Detection of Adult Polycystic Kidney Disease: Data for Genetic Counselling," American Journal of Medical Genetics 18: 45-53.

Bogdanova, N., B. Dworniczak, D. Dragova, V. Todorow, D. Dimitrakov, K. Kalinov, J. Hallmayer, J. Horst, and L. KalaydJIEVA. 1995. "Genetic Heterogeneity of Polycystic Kidney Disease in Bulgaria," Human Genetics 95: 645-50.

Bransch, W., and F. Schacht. 1933. "Pathological and Clinical Data Concerning Polycystic Kidney," Surgery, Gynecology Obstetrics 57: 467-75.

Brackenridge, R., and J. Elder. 1998. Medical Selection of Life Risks, 4th ed. New York: Macmillan.

Brendan, J., and P. Parfrey. 1991. "Autosomal Dominant Polycystic Kidney Disease and End Stage Renal Disease," Seminar Dialysis 4: 426-32.

Churchill, D., J. Bear, J. Morgan, R. Payne, P. McManamon, and H. Gault. 1984. "Prognosis of Adult Onset Polycystic Kidney Disease Re-evaluated," Kidney International 26: 190-93.

Collett, D. 1994. Modelling Survival Data in Medical Research. London: Chapman \& Hall.

Conte, S. D., and C. de Boor. 1972. Elementary Numerical Analysis. New York: McGraw-Hill.

Coto, E., S. Aguado, J. Alvarez, M. Menendez Dias, and G. LopezLarrea. 1992. "Genetic and Clinical Studies in Autosomal Dominant Polycystic Kidney Disease Type 1," Journal of Medical Genetics, 26: 190-93.

DalgaARd, O. 1957. "Bilateral Polycystic Disease of the Kidneys: A Follow Up of Two Hundred and Eighty Four Patients and Their Families," Acta Medica Scandinavica, S328: 1-255.

de Almeida, E., M. Martins, S. de Almeida, and J. Lavinha. 1999. "Long-Term Follow-Up of a Family with Autosomal Dominant Polycystic Kidney Disease Type 3," Neprology Dialysis Transplantation 14(3): 631-34.

de Bono, D., And D. Evans. 1977. "The Management of Polycystic Kidney Disease with Special Reference to Dialysis and 
Transplantation," Quarterly Journal of Medicine XLVI(183): 353-63.

Demetriou, K., G. Tziakouri, K. Anniou, A. Elefftheriou, M. Koptides, A. Nigolaou, C. Constantinou-Deltas, and A. Pierides. 2000. "Autosomal Dominant Polycystic Kidney Disease Type 2: Ultrasound, Genetic and Clinical Correlations," Nephrology Dialysis Transplantation 15: 205-11.

Dinani, A., D. Grimshaw, N. Robjohns, S. Somerville, A. Spry, and J. Staffurth. 2000. A Critical Review: Report of the Critical Illness Healthcare Study Group. London: Staple Inn Actuarial Society.

Dobin, A., W. Kimberling, W. Pettinger, J. Bailey-Wilson, Y. ShuGART, ANd P. Gabow. 1993. "Segregation Analysis of Autosomal Dominant Polycystic Kidney Disease," Genetic Epidemiology 10(3): 189-200.

Fick, G., A. Johnson, and P. Gabow. 1992. "Health Insurance and Life Insurance in Patients with Autosomal Dominant Polycystic Kidney Disease," Kidney International 45: 1153-62.

Franz, K., ANd F. Reubi. 1983. "Rate of Functional Deterioration in Polycystic Kidney Disease," Transplantation 23: 52629.

Gabow, P., M. Johnson, W. Kaenny, W. Kimberling, D. Lezotte, I. Duley, AND R. Jones. 1992. "Factors Affecting the Progression of Renal Disease in Autosomal Dominant Polycystic Kidney Disease," Kidney International 41: 1311-19.

Geberth, R., E. Ritz, M. Zeier, and E. Stier. 1995a. "Anticipation of Age at Renal Death in Autosomal Dominant Polycystic Kidney Disease?" Nephrology Dialysis Transplantation 10(9): 1603-6.

Geberth, R., E. Ritz, E. Stier, G. Mayer, M. Rambausek, and M. Zeier. 1995b. "More Adverse Renal Prognosis of Autosomal Dominant Polycystic Kidney Disease in Families with Primary Hypertension," Journal of the American Society of Nephrology 6(6): 1643-8.

Golin, C., A. Johnson, G. Fick, and P. Gabow. 1996. "Insurance for Autosomal Dominant Polycystic Kidney Disease Patients Prior to End-Stage Renal Disease," American Journal of Kidney Diseases 27(2): 220-3.

Gonzalo, A., A. Gallego, J. San Millan, and J. Ortun. 1996. "Anticipation of End-Stage Renal Disease in Autosomal Dominant Polycystic Kidney Disease," Nephrology Dialysis Transplantation 11(6): 21-3.

Gonzalo, A., M. Rivera, C. Quereda, and J. Ortun. 1990. "Clinical Features and Prognosis of Adult Polycystic Kidney Disease," American Journal of Nephrology 10: 470-4.

Gretz, N., M. Zeier, S. Geberth, M. Strauch, and E. Ritz. 1989. "Is Gender a Determinant for Evolution of Renal Failure? A Study in Autosomal Dominant Polycystic Kidney Disease," American Journal of Kidney Diseases XIV(3): 178-83.

Hadimeri, H., G. Norden, S. Friman, and G. Nyberg. 1997. "Autosomal Dominant Polycystic Kidney Disease in a Kidney Transplant Population," Nephrology Dialysis and Transplantation 12: 1431-6.

HARris, P. 1995. "Molecular Genetics of APKD," Contributions to Nephrology 115: 8-15.

Hateboer, N., N. Bogdanova, M. Dijk, E. Coto, A. Saggar-Malik, J. San Millan, R. Torra, D. Ravine, and M. Breuning, for the
European PKD1-PKD2 Study Group. 1999. “Comparison of Phenotypes of Polycystic Kidney Disease Types 1 and 2. European PKD1-PKD2 Study Group," The Lancet 353: 103-7.

International Polycystic Disease Consortium. 1995. "Polycystic Kidney Disease: The Complete Structure of the PKD1 Gene and Its Protein," Cell 81: 289-98.

Johnson, A., and P. Gabow. 1997. "Identification of Patients with Autosomal Dominant Polycystic Kidney Disease at Highest Risk of End-Stage Renal Disease," Journal of Medical Genetics 34: 827-30.

Kimberling, W., S. Pieke, J. Kenyon, and P. Gabow. 1990. "An Estimate of the Proportion of Families with Autosomal Dominant Polycystic Kidney Disease Unlinked to Chromosome 16" (abstract), Kidney International 37: 249.

Koptides, M., M. Mean, K. Demetriou, A. Pierides, and C. Deltas. 2000. "Genetic Evidence for a Trans-heterozygous Model for Cystogenesis in Autosomal Dominant Polycystic Kidney Disease," Human Molecular Genetics 9(3): 447-52.

Macdonald, A. S. 1997. "An Actuarial Survey of Statistical Models for Decrement and Transition Data. II: Competing Risks, Non-parametric and Regression Models," British Actuarial Journal 2: 429-48.

- 1999. "Modeling the Impact of Genetics on Insurance," North American Actuarial Journal 3(1): 83-101.

— . 2001. "Moratoria on the Use of Genetic Tests and Family History for Mortgage-Related Life Insurance," British Actuarial Journal: Forthcoming

Macdonald, A. S., and D. J. Pritchard. 2000. "A Mathematical Model of Alzheimer's Disease and the ApoE Gene," ASTIN Bulletin 30: 69-110.

—. 2001. "Genetics, Alzheimer's Disease, and Long-Term Care Insurance," North American Actuarial Journal 5(2): $54-78$.

Macdonald, A. S., H. R. Waters, and C. T. Wekwete. 2003a. "The Genetics of Breast and Ovarian Cancer. I: A Model of Family History," Scandinavian Actuarial Journal, 1-27.

. 2003b. "The Genetics of Breast and Ovarian Cancer. II: A Model of Critical Illness Insurance," Scandinavian Actuarial Journal, 28-50.

McCormick, A., D. Fleming, and J. Charlton. 1995. Morbidity Statistics from General Practice: Fourth National Study 1991-1992, Series MB5 No. 3. Washington, D.C.: OPCS, Government Statistical Service.

Mochizuki, T., G. Wu, T. Hayashi, S. L. Xenophontos, B. Veldhuisen, J. J. Saris, D. M. Reynolds, Y. Cai, P. A. Gabow, A. Pierides, W. J. Kimberling, M. H. Breuning, C. Constantinou Deltas, D. J. M. Peters, and S. Somlo. 1996. "PKD2, a Gene for Polycystic Kidney Disease That Encodes an Integral Membrane Protein," Science 272: 1339-42.

Nicolau, G., R. Torra, G. Badenas, R. Vilana, L. Bianchi, R. Gilabert, A. Darnell, and C. Bru. 1999. "Autosomal Dominant Polycystic Kidney Disease Types 1 and 2: Assessment Sensitivity for Diagnosis," Radiology 213: 273-6.

Office for National Statistics (O.N.S.). 1999. Cancer 19711997 CD-ROM. London: O.N.S.

Office of Population Gensuses and Surveys (O.P.C.S.). 1991. 1990 
Mortality Statistics: Cause. Series DH 12 No. 17., London: O.P.C.S.

—. 1993a. 1991 Mortality Statistics: Cause. Series DH 12 No. 18. London: O.P.C.S.

_ 1993b. 1992 Mortality Statistics: Cause. Series DH 12 No. 19. London: O.P.C.S.

Papadopoulou, D., D. Tsakiris, and M. Papadimitriou. 1999. "The Use of Ultrasonography and Linkage Studies for Early Diagnosis of Autosomal Dominant Polycystic Kidney Disease," Renal Failure 21(1): 67-84.

Parfrey, P., M. John, J. Bear, J. Morgan, B. Cramer, P. McManamon, M. Gault, D. Churchill, M. Singh, R. Hewitt, S. Somlo, and S. ReEders. 1990. "The Diagnosis and Prognosis of Autosomal Dominant Polycystic Kidney Disease," New England Journal of Medicine 323(16): 1085-90.

Pasternak, J. J. 1999. An Introduction to Human Molecular Genetics. Bethesda, MD: Fitzgerald Science Press.

Press, W. H., S. A. Teukolsky, W. T. Vetterling, and B. P. Flannery. 1992. Numerical Recipes in C: The Art of Scientific Computing, 2nd ed. Cambridge: Cambridge University Press.

Ravine, D., R. Walker, R. Gibson, S. Forrest, R. Richards, K. Friend, L. Sheffield, P. Kincaid-Smith, and D. Danks. 1992. "Phenotype and Genotype Heterogeneity in Autosomal Dominant Polycystic Kidney Disease," The Lancet 340: 1330-3.

Rossetti, S., L. Strmecki, V. Gamble, S. Burton, V. Sneddon, B. Peral, S. Roy, A. Bakkalogu, R. Komel, C. G. Winearls, and P. C. HARris. 2001. "Mutation Analysis of the Entire PKD1 Gene: Genetic and Diagnostic Implications," American Journal of Human Genetics 68: 46-63.

Schneider, M. G., A. M. Rodriguez, H. Nomura, J. Zhou, G. C. Morton, S. T. Reeders, and S. Weremowicz. 1996. "A Gene Similar to PKD1 Maps to Chromosome 4q22: A Candidate Gene for PKD2," Genomics 38: 1-4.
Stewart, J., R. Dundas, R. Howard, A. Rudd, and C. Wolfe. 1999. "Ethnic Differences in Incidence of Stroke: Prospective Study with Stroke Register," British Medical Journal 318: 967-71.

Thomas, R., R. McConnell, J. Whittacker, P. KirkPatrick, J. BradLEY, AND R. SANDFORD. 1999. "Identification of Mutations in the Repeated Part of the Autosomal Dominant Polycystic Kidney Disease Type 1 Gene, by Long-Range PCR," American Journal of Human Genetics 65: 39-49.

Torra, R., G. Badenas, A. Darnell, G. Nicolau, V. Volpini, L. Revert, And X. Estrvill. 1996. "Linkage, Clinical Features and Prognosis of Autosomal Dominant Polycystic Kidney Disease Types 1 and 2," Journal of the American Society of Nephrology 7(10): 2142-51.

Torra, R., A. Darnell, X. Estivill, A. Botey, and L. Revert. 1995. "Interfamilial and Intrafamilial Variability of Clinical Expression in ADPKD," Contributions to Nephrology 115: 97-101.

U. S. Renal Diseases System (USRDS). 1999. Annual Report of the United States Renal Diseases System. Washington, D.C.: USRDS.

Whtson, M., and V. Torres. 1996. Polycystic Kidney Disease. Oxford: Oxford University Press.

Wright, G., A. Hughes, K. Larkin, G. Doherty, and N. Nevin. 1993. "Genetic Linkage Analysis, Clinical Features and Prognosis of Autosomal Dominant Polycystic Kidney Disease in Northern Ireland," Quarterly Journal of Medicine 86(7): 459-63.

Discussions on this paper can be submitted until October 1, 2003. The authors reserve the right to reply to any discussion. Please see the Submission Guidelines for Authors on the inside back cover for instructions on the submission of discussions. 